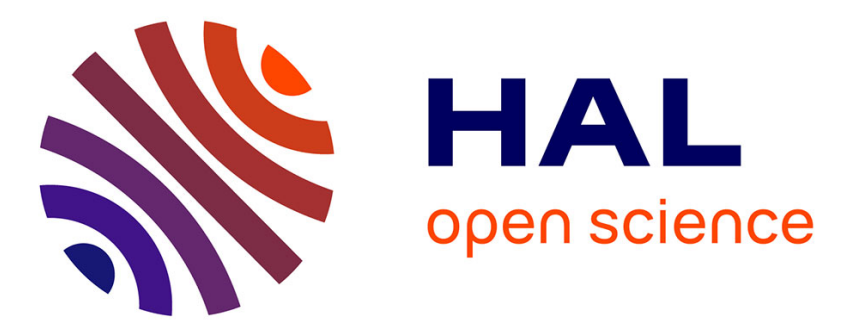

\title{
Zinc and copper complexes of stilbene iminopyridine ligands with eta 2-Olefin binding mode
}

Awatef Ayadi, Mohamed-Ali Benmensour, Yohan Cheret, Abdou Boucekkine, Abdelkrim El-Ghayoury

\section{- To cite this version:}

Awatef Ayadi, Mohamed-Ali Benmensour, Yohan Cheret, Abdou Boucekkine, Abdelkrim El-Ghayoury. Zinc and copper complexes of stilbene iminopyridine ligands with eta 2-Olefin binding mode. Journal of Organometallic Chemistry, 2018, 858, pp.14-22. 10.1016/j.jorganchem.2018.01.002 hal-01737370

HAL Id: hal-01737370

https://hal-univ-rennes1.archives-ouvertes.fr/hal-01737370

Submitted on 18 Apr 2018

HAL is a multi-disciplinary open access archive for the deposit and dissemination of scientific research documents, whether they are published or not. The documents may come from teaching and research institutions in France or abroad, or from public or private research centers.
L'archive ouverte pluridisciplinaire HAL, est destinée au dépôt et à la diffusion de documents scientifiques de niveau recherche, publiés ou non, émanant des établissements d'enseignement et de recherche français ou étrangers, des laboratoires publics ou privés. 
Zinc and Copper Complexes of Stilbene Iminopyridine Ligands with $\eta 2$ Olefin Binding Mode

Awatef Ayadi ${ }^{1,2}$, Mohamed-Ali Benmensour ${ }^{3}$, Yohan Cheret, ${ }^{1}$ Abdou Boucekkine ${ }^{4}$, Abdelkrim El-Ghayoury ${ }^{1 *}$

${ }^{1}$ Université d'Angers, CNRS UMR 6200, Laboratoire MOLTECH-Anjou, 2 bd Lavoisier, 49045 Angers Cedex, France.

${ }^{2}$ Laboratoire de Physico-chimie de l'état solide, Université de Sfax, Route de Soukra ; Km 4 ; BP : 802, 3038, Sfax, Tunisia.

${ }^{3}$ Faculté de Chimie USTHB Alger and Département de Chimie, UMMTO Tizi-Ouzou, Algeria. ${ }^{4}$ ISCR UMR 6226 CNRS-Université de Rennes 1, Campus de Beaulieu, 35042 Rennes Cedex, France.

* E-mail: abdelkrim.elghayoury@univ-angers.fr; Tel: +33 241735492: Fax: +33 241735405

\begin{abstract}
Two stilbene based iminopyridine ligands (L1-L2) synthesized by a condensation reaction between N,N-Dimethyl-4,4'-azodianiline and 2-pyridinecarboxaldehyde or 2,6pyridinedicarboxaldehyde, with $73 \%$ and $65 \%$ yield, are described. The two ligands have been characterized by elemental analysis and spectroscopic techniques. The complexation of ligand $\mathbf{L 1}$ with $\mathrm{ZnCl}_{2}$ afforded neutral tetrahedral zinc(II) metal complex $\mathbf{C 1}$ formulated as

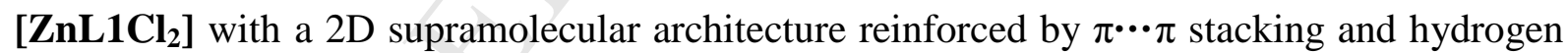
bonding in the solid state. Interestingly in the case of copper(I) complex $\mathbf{C 2}$, ligand $\mathbf{L} \mathbf{1}$ acts as a ditopic ligand since it coordinates one $\mathrm{Cu}(\mathrm{I})$ with an iminopyridyl fragment and a second metal center with an $\eta 2$-olefin binding mode giving rise to a $1 \mathrm{D}$-polymeric structure. The coordination sphere is completed with an acetonitrile solvent molecule leading to a distorted tetrahedral geometry around copper cation and the resulting coordination polymer can be formulated as $\left\{\left[\mathbf{C u}(\mathbf{L 1})_{2} \mathbf{C H}_{3} \mathbf{C N}\right] \mathbf{B F}_{4}\right\}$. In addition complexation of $\mathbf{L 2}$ with zinc chloride afforded complex $\mathbf{C 3}$ formulated as $\left[\mathbf{Z n L 2} \mathbf{C l}_{2}\right]$. DFT and TDDFT computations permitted to investigate the frontier MOs of all species and to assign their UV-visible absorption bands.
\end{abstract}


Keywords: Iminopyridine, olefin, Zinc complexes, copper(I) coordination polymer, X-ray diffraction, DFT computations.

\section{Introduction}

Photochromic compounds are defined as being chemical species that undergo a reversible chemical transformation between two forms having different absorption spectra by light irradiation [1]. Different types of transformations such as cis-trans isomerization, ionization, pericyclic ring-opening and ring-closing reactions, as well as intramolecular group transfer reactions, are known [2]. Such chemical changes have been the basis of a variety of applications ranging from consumer and cosmetic products, photochromic inks, ophthalmic and sunglass lenses, optical filters, optoelectronic devices and optical memories [3]. Thus, azobenzene and stilbene derivatives have been reported to possess unique photochromic properties with stable cis and trans geometries related with two efficient and reversible photoisomerization processes on their $-\mathrm{N}=\mathrm{N}-$ and $-\mathrm{C}=\mathrm{C}-$ double bonds, respectively [4]. Moreover, this above mentioned reversible isomerization is the basis for many functional materials with applications in nonlinear optics [5], optical storage media [6], chemosensors [7] and optical switches [8]. In contrast combining photochromic units with a coordinating or a binding unit is a very successful strategy for the design of photochromic transition metal complexes [9]. On this ground, pyridine containing Schiff bases, such as 2-iminopyridyls and 2,6-bisiminopyridyls form stable complexes with various transition metals. They have been used, for instance, in metallo-organic self-assembling media to produce discrete metallosupramolecular helicates [10], cages [11] and capsules [12] and have also been utilized with a variety of transition metals in catalysis [13]. In addition, $\mathrm{d}^{10}$ metal complexes of Schiff base ligands have been successfully used in co-sensitized solar cells [14]. In addition, $\mathrm{d}^{10}$ copper(I) cation is known to interact with ethylene in biological systems [15] and this has inspired a great deal of work to prepare and isolate stable copper(1) olefin complexes. This has been achieved using neutral N-donor heterocyclic compounds, including bis(pyrazolyl)methanes [16], dipyridylamine [17] phenanthroline [18] and bipyridines [16-19].

Recently, we described the synthesis of a tetrathiafulvalene based iminopyridine ligand and demonstrated the increase in its nonlinear optical response upon metal complexation with zinc(II) ion [20]. Moreover, we have shown a dramatic increase in the nonlinear optical 
absorption of an azo-based iminopyridine ligand upon complexation with $\mathrm{ZnCl}_{2}$ [21]. As a continuation of our work, we are reporting herein the synthesis and full characterization of two iminopyridine-appended stilbene ligands L1, which has been reported in the literature during the ongoing of the present work [22], and $\mathbf{L} \mathbf{2}$ as well as the preparation of two new zinc(II) and copper(I) metal complexes with ligand $\mathbf{L} \mathbf{1}$ and a zinc(II) complex of ligand $\mathbf{L 2}$. Interestingly, coordination of copper(I) with ligand $\mathbf{L} \mathbf{1}$ gives rise to a stable copper(I)-olefin coordination polymer where $\mathbf{L} \mathbf{1}$ is acting as a ditopic ligand coordinating with both the iminopyridyl and olefin fragments. DFT computations were carried out in order to investigate the electronic structure and properties of the species under consideration. The nonlinear optical properties of these compounds which will be compared with the corresponding azobased materials are currently under investigations and will be published in due time.

\section{Experimental}

\subsection{General remarks}

Commercially available reagents and all solvents for synthesis were of analytical grade and were used without further purification. Reactions were carried out under nitrogen. Nuclear magnetic resonance spectra were recorded on a Bruker $300 \mathrm{MHz}$ spectrometer. The following abbreviations are used to represent the multiplicity of the signals: s (singlet), $d$ (doublet), the spin-spin coupling constants $(\mathrm{J})$ were measured. Infrared spectra were recorded on a Bruker vertex 70 spectrometer; the measurements were recorded in 400 to $4000 \mathrm{~cm}^{-1}$ range. Elemental analyses (C, H and N) were performed on a Thermo-Scientific Flash 2000 Organic. Mass spectrometry measurements were carried out on a Bruker Biflex-III TM which uses 1,8,9-trihydroxyanthracene as a matrix. UV-Visible absorption spectra were recorded at room temperature in quartz cuvettes using a Perkin Elmer spectrophotometer.

\subsection{Crystallography}

Experimental X-ray diffraction data on single crystals were collected at room temperature using a Bruker Nonius Kappa CCD diffractometer operating with $\operatorname{Mo}-\mathrm{K} \alpha(\lambda=$ $0.71073 \AA$ ) for complexes $\mathbf{C 1}$ and $\mathbf{C 2}$. For complex $\mathbf{C 3}$ data were collected at $150 \mathrm{~K}$ on an Agilent SuperNova diffractometer equipped with an Atlas CCD detector and mirror monochromated micro-focus $\mathrm{Cu}-\mathrm{K} \alpha$ radiation $(\lambda=1.54184 \AA)$. All the structures were solved 
by direct methods, expanded and refined on $\mathrm{F}^{2}$ by full matrix least-square techniques using SHELX97 programs. All non-H atoms were refined anisotropically and the $\mathrm{H}$ atoms were included in the calculation without refinement. Multi-scan empirical absorption was corrected using the SADABS program (Bruker AXS area detector scaling and absorption correction,v2008/1) for complexes $\mathbf{C 1}$ and $\mathbf{C 2}$ and using the CrysAlisPro program (CrysAlisPro, Agilent Technologies, V1.171.37.35 g, 2014) for complex C3. Details of the single crystal X-ray experiments and crystal data are summarized in Table 1.

Table 1 : Crystal data and structure refinement for $(\mathbf{C 1}),(\mathbf{C 2})$ and $(\mathbf{C 3})$.

\begin{tabular}{|c|c|c|c|}
\hline compound & C1 & $\mathrm{C2}$ & C3 \\
\hline empirical formula & $\mathrm{C}_{44} \mathrm{H}_{42} \mathrm{Cl}_{4} \mathrm{~N}_{6} \mathrm{Zn}_{2}$ & $\mathrm{C}_{48} \mathrm{H}_{48} \mathrm{~B}_{2} \mathrm{Cu}_{2} \mathrm{~F}_{8} \mathrm{~N}_{8}$ & $\mathrm{C}_{39} \mathrm{H}_{37} \mathrm{Cl}_{2} \mathrm{~N}_{5} \mathrm{Zn}$ \\
\hline fw & 927.38 & 1037.64 & 712.01 \\
\hline$T(\mathrm{~K})$ & 293(2) & 293(2) & $150.0(10)$ \\
\hline wavelength $(\AA)$ & 0.71073 & 0.71073 & 1.54184 \\
\hline cryst syst & monoclinic & monoclinic & monoclinic \\
\hline space group & $\mathrm{P} 2{ }_{1} / \mathrm{c}$ & $\mathrm{Cc}$ & $\mathrm{P} 2{ }_{1} / \mathrm{n}$ \\
\hline$a(\AA)$ & $16.6751(15)$ & $15.75(3)$ & $14.2985(13)$ \\
\hline$b(\AA)$ & $10.3663(3)$ & $18.914(10)$ & $9.5166(7)$ \\
\hline$c(\AA)$ & $26.0256(2)$ & $8.093(10)$ & $25.751(2)$ \\
\hline$\alpha(\operatorname{deg})$ & $90 /$ & 90 & 90 \\
\hline$\beta(\operatorname{deg})$ & $100.560(8)$ & $107.76(10)$ & $100.456(9)$ \\
\hline$\gamma(\operatorname{deg})$ & 90 & 90 & 90 \\
\hline$V\left(\AA^{3}\right)$ & $4423(6)$ & $2296(5)$ & $3445.9(5)$ \\
\hline$Z$ & 4 & 2 & 4 \\
\hline$D_{\mathrm{c}}\left(\mathrm{g} \mathrm{cm}^{-3}\right)$ & 1.393 & 1.501 & 1.372 \\
\hline abs coeff $\left(\mathrm{mm}^{-1}\right)$ & 1.364 & 1.004 & 2.689 \\
\hline
\end{tabular}


ACCEPTED MANUSCRIPT

\begin{tabular}{|c|c|c|c|}
\hline$F(000)$ & 1904 & 1064 & 1480 \\
\hline cryst size $\left(\mathrm{mm}^{3}\right)$ & $0.47 \times 0.09 \times 0.06$ & $0.21 \times 0.03 \times 0.015$ & $0.23 \times 0.064 \times 0.018$ \\
\hline $\begin{array}{l}\theta \text { range for data } \\
\text { collection (deg) }\end{array}$ & $2.19-25.51$ & $2.79-26.01$ & $3.14-79.20$ \\
\hline reflns collected & 17923 & 6105 & 13396 \\
\hline indep reflns & 4584 & 3899 & 6972 \\
\hline completeness (\%) & 97.5 & 97.9 & 99.2 \\
\hline refinement method & $\begin{array}{l}\text { full-matrix least } \\
\text { squares on } F^{2}\end{array}$ & $\begin{array}{ll}\text { full-matrix } & \text { least } \\
\text { squares on } F^{2} & \end{array}$ & $\begin{array}{l}\text { full-matrix least } \\
\text { squares on } F^{2}\end{array}$ \\
\hline data/restraints/param & $4584 / 0 / 509$ & $3899 / 2 / 310$ & $6972 / 0 / 428$ \\
\hline GOF on $F^{2}$ & 1.039 & 1.012 & 0.919 \\
\hline $\begin{array}{l}\text { final } R \text { indices }[I> \\
2 \sigma(I)]\end{array}$ & $\begin{array}{l}\mathrm{R} 1=0.0938, \mathrm{wR} 2 \\
=0.2328\end{array}$ & $\begin{array}{l}\mathrm{R} 1=0.0671, w \mathrm{R} 2= \\
0.1468\end{array}$ & $\begin{array}{l}\mathrm{R} 1=0.0439, \mathrm{wR} 2 \\
=0.0936\end{array}$ \\
\hline$R$ indices (all data) & $\begin{array}{l}\mathrm{R} 1=0.1764, \mathrm{wR} 2 \\
=0.3050\end{array}$ & $\begin{array}{l}\mathrm{R} 1=0.1016, \mathrm{wR} 2= \\
0.1646\end{array}$ & $\begin{array}{l}\mathrm{R} 1=0.0846, \mathrm{wR} 2 \\
=0.1053\end{array}$ \\
\hline $\begin{array}{l}\text { largest diff. peak } \\
\text { and hole }\left(e \AA^{-3}\right)\end{array}$ & 0.560 and -0.658 & 1.069 and -0.606 & 0.430 and -0.447 \\
\hline
\end{tabular}

\subsection{Synthesis of compounds $\mathbf{L 1}, \boldsymbol{C 1}, \boldsymbol{C 2}, \mathrm{L} 2$ and $\boldsymbol{C 3}$}

2.3.1. Synthesis of $N, N$-dimethyl-4-((E)-(pyridin-2-ylmethylene) amino)styryl) aniline (L1)

This ligand $\mathbf{L} \mathbf{1}$ has been prepared with a slight modification from the procedure described earlier [22].

A solution of (E)-4-(4-aminostyryl)-N,N-dimethylaniline $(0.200 \mathrm{~g}, 0.61 \mathrm{mmol})$ and 2formylpyridine $(0.065 \mathrm{~g}, 0.61 \mathrm{mmol})$ in ethanol $(20 \mathrm{~mL})$ and a few drops of acetic acid were heated under reflux overnight. After cooling to room temperature, the precipitate formed was filtered off and washed with ethanol. The desired product L1 was obtained as an orange powder with $73 \%$ yield $(0.147 \mathrm{~g}, 0.449 \mathrm{mmol}) .{ }^{1} \mathrm{H}$ NMR $\left(300 \mathrm{MHz}, \mathrm{CDCl}_{3}\right) \delta / \mathrm{ppm}: 8.72$ (d, $1 \mathrm{H}, \mathrm{J}=4.20 \mathrm{~Hz}, \mathrm{H} 1), 8.66$ (s, 1H, H6), 8.22 (d, 1H, J = $7.92 \mathrm{~Hz}, \mathrm{H} 4), 7.85$ (m, 1H, H2), 7.53 
(d, 2H, J = 8.40 Hz, H9 and H11), 7.43 (d, 2H, J = $8.80 \mathrm{~Hz}, \mathrm{H} 16$ and H20), 7.35 (m, 1H, H3), $7.31(\mathrm{~d}, 2 \mathrm{H}, \mathrm{J}=8.50 \mathrm{~Hz}, \mathrm{H} 8$ and H12), 7.08 (d, 1H, J = 16.30 Hz, H13 or H14), 6.93 (d, 1H, J $=16.30 \mathrm{~Hz}, \mathrm{H} 14$ or H13), 6.85 (d, 2H, J = $8.80 \mathrm{~Hz}, \mathrm{H} 17$ and H19), 2.99 (s, 6H, H21 and H22). ${ }^{13} \mathrm{C}$ NMR (75 MHz, $\mathrm{CDCl}_{3}$ ) $\delta / \mathrm{ppm}: 159.46$ (C6), 154.80 (C18), 150.21(C5), 149.74 (C1), 149.14 (C7), 137.23 (C3), 136.67 (C10), 128.99 (C13 or C14), 127.65 (C9 and C11), 126.85 (C16 and C20), 125.73 (C2), 125.01 (C15), 123.69 (C13 or C14), 121.88 (C8 and C12), 121.74 (4), 115.31 (C17 or C19), 112.47 (C17 or C19), 40.48 (C21 and C22). Anal.

Calc. for $\mathrm{C}_{22} \mathrm{H}_{21} \mathrm{~N}_{3}: \mathrm{C}, 80.70 \%$;, $6.46 \%$;, $12.83 \%$. Found: C, $80.72 \% ; \mathrm{H}, 6.21 \%$; $12.56 \%$. Selected IR bands $\left(\mathrm{cm}^{-1}\right): v=1603,1519,1348,1076,828$. MALDI-TOF MS calcd: $\mathrm{m} / \mathrm{z}=327.17$ Da. Found: $\mathrm{m} / \mathrm{z}=327.4$. HR-MS (M): for $\mathrm{C}_{22} \mathrm{H}_{21} \mathrm{~N}_{3}: 327.1735$. Found 327.1730 $\left(\mathrm{M}^{+}\right)$.

\subsubsection{Zinc(II) complex $\left[\mathrm{ZnLICl}_{2}\right](\mathrm{C1})$}

In a test tube, a solution of ligand $\mathbf{L 1}(0.020 \mathrm{~g}, 0.06 \mathrm{mmol})$ in $\mathrm{CH}_{2} \mathrm{Cl}_{2}(5 \mathrm{~mL})$ was mixed with a solution of $\mathrm{ZnCl}_{2}(0.008 \mathrm{~g}, 0.06 \mathrm{mmol})$ in $\mathrm{CH}_{3} \mathrm{CN}(5 \mathrm{~mL})$ and ultrasonicated for 2 minutes. On top of the resulting solution, a layer of diethyl ether was added, which led to the formation of single crystals of complex $\mathbf{C 1}$ after two days. Yield: $81 \%$ (0.023 g, $0.049 \mathrm{mmol}) .{ }^{1} \mathrm{H} \mathrm{NMR}$

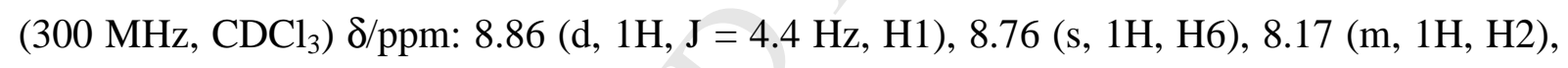
$7.92(\mathrm{~d}, 1 \mathrm{H}, \mathrm{J}=7.60 \mathrm{~Hz}, \mathrm{H} 4), 7.75(\mathrm{~d}, 2 \mathrm{H}, \mathrm{J}=8.5 \mathrm{~Hz}, \mathrm{H} 9$ and H11), 7.75 (m, 1H, H3), 7.56 (d, 2H, J = 8.4 Hz, H8 and H12), 7.44 (d, 2H, J = 8.7 Hz, H16 and H20 ), 7.13 (d, 1H, J= 16.4 Hz, H13 or H14), 6.90 (d, 1H, J= $16.0 \mathrm{~Hz}, \mathrm{H} 14$ or H13 ) 6.72 (d, 2H, J= $8.8 \mathrm{~Hz}, \mathrm{H} 17$ and H19), 3.01 (s, 6H, H21 and H22). ${ }^{13} \mathrm{C}$ NMR (75 MHz, $\mathrm{CDCl}_{3}$ ) $\delta / \mathrm{ppm}: 159.46$ (C6), 154.76 (C18), 150.19 (C5), 149.74 (C1), 149.11 (C7), 137.23 (C3), 136.70 (C10), 128.98 (C13 or C14), 127.66 (C9 or C11), 127.19 (C9 and C11), 126.85 (C16 and C20), 125.70 (C2), 125.39 (C15), 125.04, 124.63, 123.66, 121.90, 121.75, 115.32, 112.46, 40.49. Anal. Calc. for $\mathrm{C}_{22} \mathrm{H}_{21} \mathrm{~N}_{3} \mathrm{ZnCl}_{2}$ : C, $56.98 \% ; \mathrm{H}, 4.36 \%$;, $7.21 \%$. Found: C, $56.61 \%$; $4.31 \% ; \mathrm{N}, 6.95$ $\%$. Selected IR bands $\left(\mathrm{cm}^{-1}\right): v=1591,1520,1363,1098,827$. MALDI-TOF MS calcd: $\mathrm{m} / \mathrm{z}=$ 425.59 Da. Found: $\mathrm{m} / \mathrm{z}=426.0 \mathrm{HR}-\mathrm{MS}(\mathrm{M})$ : for $\mathrm{C}_{22} \mathrm{H}_{21} \mathrm{~N}_{3} \mathrm{ZnCl}$ : 426.0715. Found 426.0722 $\left([\mathrm{ZnL} 1 \mathrm{Cl}]^{+}\right)$.

\subsubsection{Copper (I) complex $\left\{\left[\mathbf{C u}(\mathrm{L1})_{2} \mathbf{C H}_{3} \mathbf{C N}\right] \mathrm{BF}_{4}\right\}(\mathrm{C} 2)$}


In a test tube, a solution of ligand $\mathbf{L 1}(0.020 \mathrm{~g}, 0.06 \mathrm{mmol})$ in $\mathrm{CH}_{2} \mathrm{Cl}_{2}(5 \mathrm{~mL})$ was mixed with a solution of $\mathrm{Cu}\left(\mathrm{CH}_{3} \mathrm{CN}\right)_{4} \mathrm{BF}_{4}(0.0094 \mathrm{~g}, 0.03 \mathrm{mmol})$ in $\mathrm{CH}_{3} \mathrm{CN}(5 \mathrm{~mL})$ and sonicated for 2 min. On top of the resulting solution, a layer of diethyl ether was added which led to the formation of single crystals of complex $\left\{\left[\mathrm{Cu}(\mathrm{L1})_{2} \mathbf{C H}_{3} \mathrm{CN}_{\mathbf{B}} \mathrm{BF}_{4}\right\} \mathbf{C 2}\right.$ after one week. Yield : $57 \%(0.013 \mathrm{~g}, 0.017 \mathrm{mmol})$. Anal. Calc. for $\mathrm{C}_{46} \mathrm{H}_{45} \mathrm{~N}_{7} \mathrm{CuBF}_{4}: \mathrm{C}, 65.29 \%$; H, $5.36 \%$; N, $11.56 \%$. Found: C, $64.97 \%$; $4.92 \%$;, $11.13 \%$. Selected IR bands $\left(\mathrm{cm}^{-1}\right): \mathrm{v}=1593$, 1597, 1473, 1440, 1050, 848. MALDI-TOF MS calcd: m/z = 717.28 Da. Found: $\mathrm{m} / \mathrm{z}=717.5$ HR-MS (M): for $\mathrm{C}_{44} \mathrm{H}_{42} \mathrm{~N}_{6} \mathrm{Cu}$ : 717.2767. Found: 717.2763 ([Cu(L1) $\left.]+\right)$.

2.3.4. Synthesis of 4,4'-((1E,1'E)-(((1E,1'E)-(pyridine-2,6-diylbis(methanylylidene $))$ bis(azanylylidene))bis(4,1-phenylene))bis(ethene-2,1-diyl))bis(N,N-dimethylaniline)(L2)

The synthesis of ligand $\mathbf{L} 2$ was similar to that of ligand L1. Thus, 4-(4-aminostyryl)-N,Ndimethyaniline $(0.200 \mathrm{~g}, 0.61 \mathrm{mmol})$ was reacted with 2,6 -pyridinedicarboxaldehyde $(0.041$ $\mathrm{g}, 0.30 \mathrm{mmol})$ using ethanol as a solvent $(20 \mathrm{~mL})$ and a few drops of acetic acid. The resulting mixture was refluxed overnight and after cooling to room temperature, the precipitate formed was filtered and washed off with ethanol to yield $65 \%$ of $\mathbf{L 2}(0.112 \mathrm{~g}, 0.194 \mathrm{mmol}) .{ }^{1} \mathrm{H}$ NMR

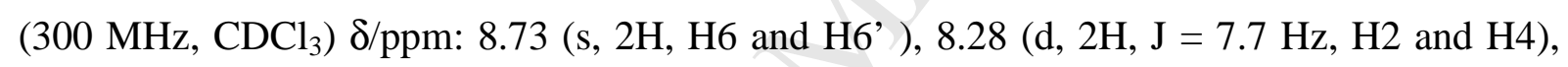
7.54(d, 4H, J= 8.5 Hz, H9, H11, H9' and H11'), 7.42 (d, 4H, J= 8.9 Hz, H16, H20, H16' and H20'), 7.34 (d, 4H, J= 8.4 Hz, H8, H12, H8' and H12'), 7.19(d, 1H, J= 7.7 Hz, 1H and H3), 7.08 (d, 2H, J= 16.4 Hz H13 and H13' or H14 and H14'), 6.93 (d, 2H, J=16.4 Hz, H14 and H14' or H13 and H13'), 6.72 (d, 4H, J= 8.9 Hz, H17, H19, H17' and H19'), 2.98 (s, 12H, $\mathrm{H} 21, \mathrm{H} 22, \mathrm{H} 21$ ' and H22'). ${ }^{13} \mathrm{C}$ NMR (75 MHz, $\left.\mathrm{CDCl}_{3}\right) \delta / \mathrm{ppm}$ : 154.76, 151.20, 149.94, $147.01,138.24,137.67,129.98,127.66,127.19,127.11,126.89,125.73,124.63,123.69$, 121.88, 121.55, 115.76, 112.53, 41.3. Anal. Calc. for $\mathrm{C}_{39} \mathrm{H}_{37} \mathrm{~N}_{5}: \mathrm{C}, 81.36 \% ; \mathrm{H}, 6.48 \%$; $12.16 \%$. Found: C, $80.98 \%$; H, $6.03 \%$; N, $11.87 \%$. Selected IR bands $\left(\mathrm{cm}^{-1}\right): v=1608$, 1519, 1346, 967, 826, 545. MALDI-TOF MS calcd: $\mathrm{m} / \mathrm{z}=575.74$ Da. Found: $\mathrm{m} / \mathrm{z}=575.6$ HR-MS (M): for $\mathrm{C}_{39} \mathrm{H}_{37} \mathrm{~N}_{5}$ : 575.3049. Found: $575.3053(\mathrm{M}+)$.

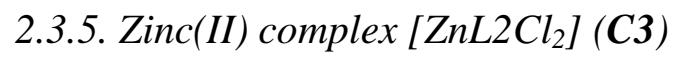

In a test tube, a solution of ligand $\mathbf{L 2}(0.020 \mathrm{~g}, 0.034 \mathrm{mmol})$ in $\mathrm{CH}_{2} \mathrm{Cl}_{2}(5 \mathrm{~mL})$ was mixed with a solution of $\mathrm{ZnCl}_{2}(0.004 \mathrm{~g}, 0.034 \mathrm{mmol})$ in $\mathrm{CH}_{3} \mathrm{CN}(5 \mathrm{~mL})$ and ultrasonicated for 2 minutes. On top of the resulting solution, a layer of diethyl ether was added which led to the 
formation of single crystals of complex $\mathbf{C 3}$ after one week with $48 \%$ yield $(0.012 \mathrm{~g}, 0.017$ mmol). ${ }^{1} \mathrm{H}$ NMR (300 MHz, $\mathrm{CDCl}_{3}$ ) $\delta / \mathrm{ppm}: 8.74$ (d, 2H, J = 8.0 Hz, H2 and H4), 8.72 (s, 2H, H6 and H6'), 7.97(d, 4H, J= 7.9 Hz, H8, H12, H8', and H12'), 7.91 (d, 1H, J= 8.1 Hz H3), 7.56 (d,4H, J= 8.6 Hz, H9, H11, H9' and H11'), 7.44 (d, 4H, J=8.90 Hz, H16, H20, H16' and H20), 7.11 (d, 2H, J= 16.3 Hz, H13 and H13' or H14 znd H14'), 6.92 (d, 2H, J= 16.8 Hz, H14 and H14' or H13 and H13') 6.72 (d, 4H, J = 8.9 Hz, H17, H19, H17' and H19') 3.01 (s, 12H, $\mathrm{H} 21, \mathrm{H} 22, \mathrm{H} 21$ ' and $\mathrm{H} 22$ '). Anal. Calc. for $\mathrm{C}_{39} \mathrm{H}_{37} \mathrm{~N}_{5} \mathrm{Cl}_{2} \mathrm{Zn}$ : C, $65.79 \% ; \mathrm{H}, 5.24 \%$; N, 9.84 \%. Found: C, $65.70 \%$; H, $5.02 \%$; N, $9.53 \%$. Selected IR bands $\left(\mathrm{cm}^{-1}\right): v=1608,1516$, 1350, 1071, 825, 601, 545. MALDI-TOF MS calcd: $\mathrm{m} / \mathrm{z}=712.03 \mathrm{Da}$. Found: $\mathrm{m} / \mathrm{z}=676.5$ HR-MS (M): for $\mathrm{C}_{39} \mathrm{H}_{37} \mathrm{~N}_{5} \mathrm{ClZn}$ : 674.2029 Found: 674.2025 ([ZnL2Cl]+).

\section{Results and discussion}

\subsection{Syntheses}

The synthesis of the stilbene derivative was started by the reaction of HornerWadsworth- Emmons, using commercially available starting compounds 4-dimethylaminobenzaldehyde and (p-nitrobenzyl)-phosphonic acid diethyl ester, to give (A) which was reduced by tin chloride to afford the corresponding amino precursor (B) as previously reported in the literature (Scheme 1) [23].

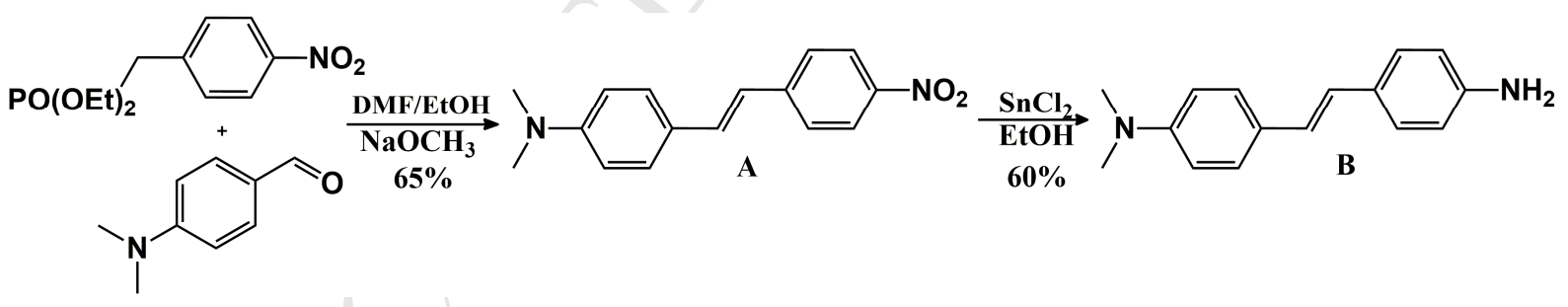

Scheme 1. Synthesis of stilbene derivative B.

This amine (B) was reacted with one equivalent of 2-pyridinecarboxaldehyde or a half equivalent of 2,6-pyridinedicarboxaldehyde in ethanol using a catalytic amount of acetic acid to give $\mathbf{L} \mathbf{1}$ or $\mathbf{L} \mathbf{2}$ to the tune of $73 \%$ and $65 \%$ respectively (Scheme 2). 


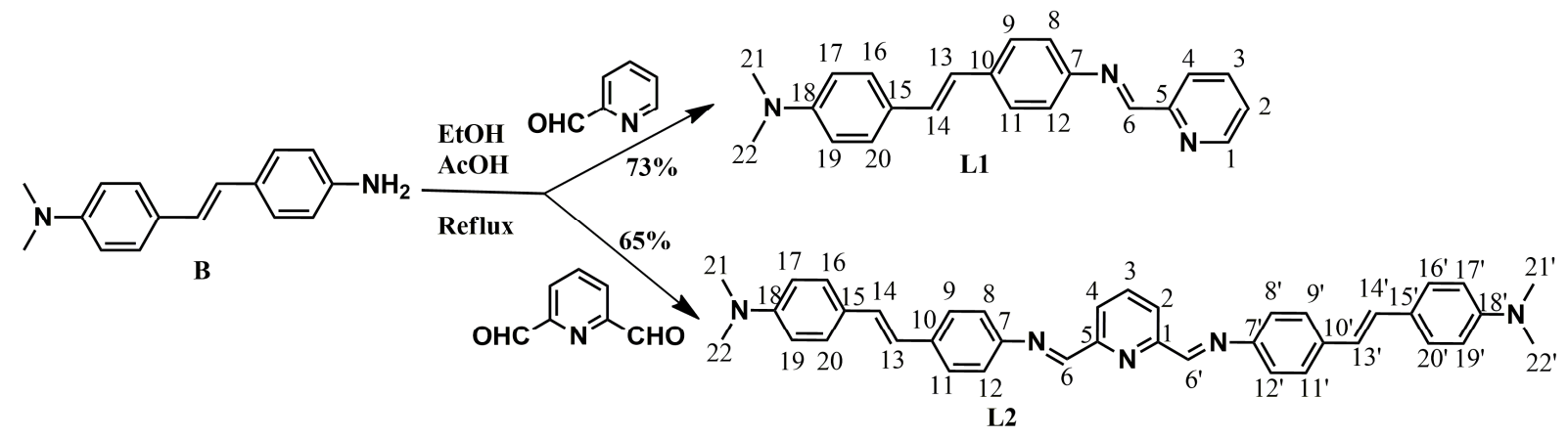

Scheme 2. Synthesis of ligands $\mathbf{L 1}$ and $\mathbf{L 2}$.

Ligand $\mathbf{L 1}$ was reacted with one equivalent of zinc chloride to form the mononuclear zinc(II) complex $\mathbf{C 1}$ formulated as $\left[\mathbf{Z n L 1 C l} \mathbf{C l}_{2}\right]$ and with a half equivalent of $\left[\mathrm{Cu}\left(\mathrm{CNCH}_{3}\right)_{4}\right] \mathrm{BF}_{4}$ to produce the corresponding copper(I) $\mathbf{C 2}$ formulated as $\left\{\left[\mathbf{C u}(\mathbf{L 1})_{2} \mathbf{C H}_{3} \mathbf{C N}_{B} \mathbf{B F}_{4}\right\}\right.$ (Scheme 3). Whilst the reaction of $\mathbf{L} \mathbf{2}$ with one equivalent of zinc chloride yielded complex $\mathbf{C} \mathbf{3}$ formulated as $\left[\mathbf{Z n L 2 C l} \mathbf{l}_{2}\right]$.

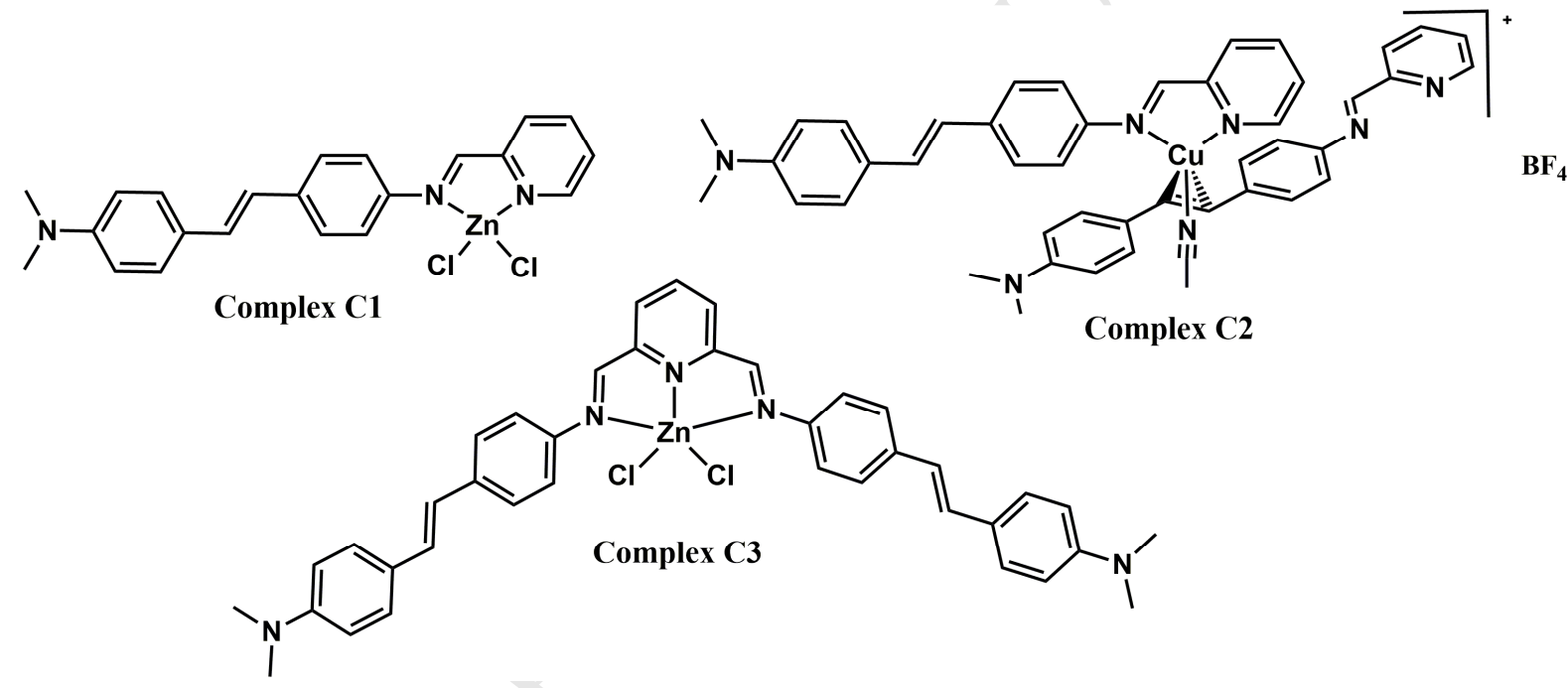

Scheme 3. Structure of complexes C1, C2 and C3.

\subsection{Description of crystal structures}

\subsubsection{Crystal structure of $\boldsymbol{C 1}$}

Suitable crystals for X-ray structural determination were grown by the slow diffusion of the mixture of the above-mentioned reactants in $\mathrm{CH}_{3} \mathrm{CN}: \mathrm{CH}_{2} \mathrm{Cl}_{2}(1 / 1, \mathrm{v} / \mathrm{v})$ into an ethylic ether layer. Complex $\mathbf{C 1}$ crystallizes in the monoclinic space group $\mathrm{P} 2{ }_{1} / \mathrm{c}$, the crystal structure being shown in Fig. 1. Note that the asymetric unit of this complex is composed of two chemically identical molecules. 
The zinc(II) ion is tetracoordinated with the expected tetrahedral geometry, the coordination sphere being formed by two chlorine atoms $(\mathrm{Cl1}, \mathrm{Cl} 2)$ and two nitrogen atoms from the iminopyridyl from the chelating ligand L1. The stereochemistry around the zinc(II) ion is slightly distorted as evidenced by the difference between the values of the angles formed by the metal center and the donor atoms. This distortion is caused by the small bite size of ligand L1, a common feature of iminopyridyl type ligands [21], which results in a significantly narrow $\mathrm{N}-\mathrm{Zn}-\mathrm{N}$ angle $\left(\mathrm{N} 1-\mathrm{Zn} 1-\mathrm{N} 279.89(9)^{\circ}\right)$ in comparison with the other angles around the zinc atom as well as the ideal tetrahedral angle. In complex C1, the Zn1-N1(pyridyl) bond is somewhat shorter than the Zn1-N2(imino) bond, and the length of 1.265(1) $\AA$ for the C6-N2 bond confirms no delocalization as has already been found for a similar azo-based complex [21].

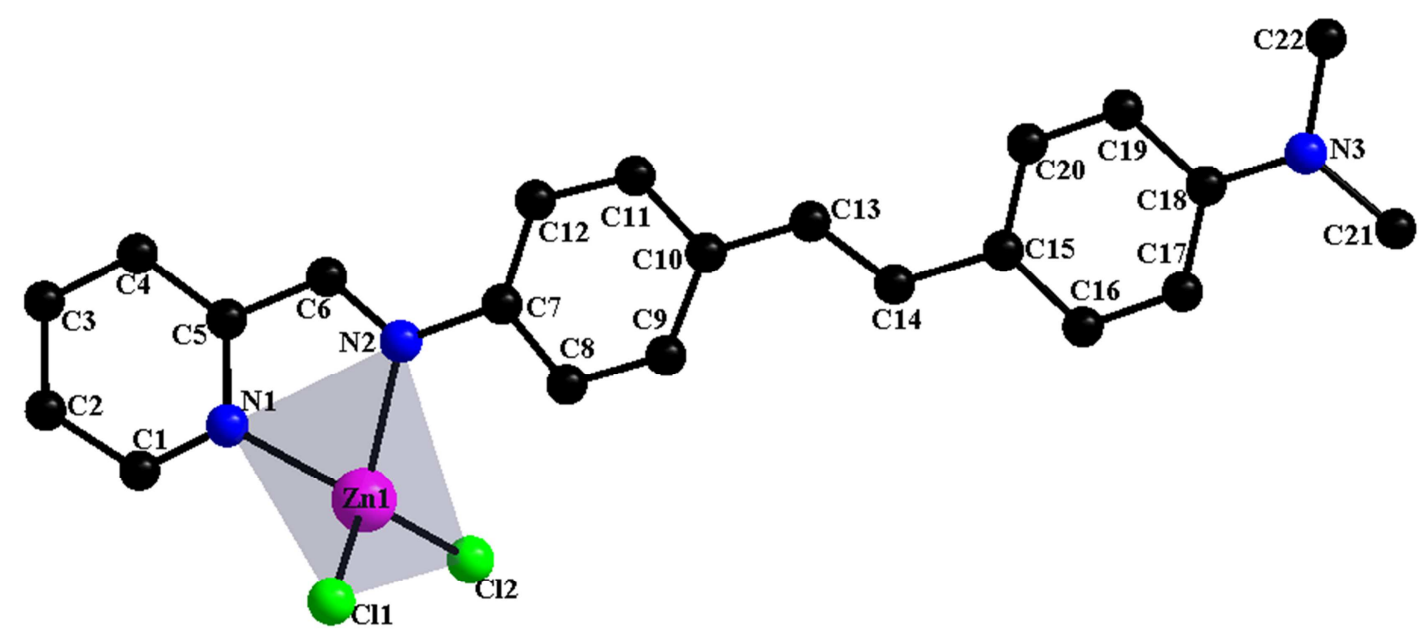

Fig. 1. Crystal structure of complex $\mathbf{C 1}$ with atom numbering scheme.

Within the crystal, each molecule of the complex interacts with two other neighboring molecules via weak hydrogen bonding established between the chlorine atoms coordinated to

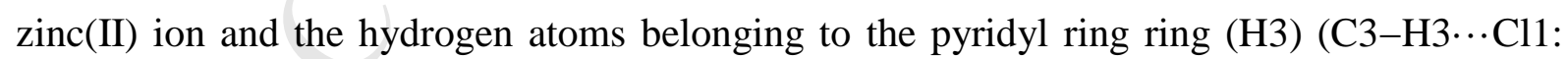
$\mathrm{H} 3 \cdots \mathrm{C} 112.85 \AA$ ), resulting in the formation of dimers that are formed with a rare $\mathrm{R}_{2}{ }^{2}(14)$ pattern (Fig. 2). 


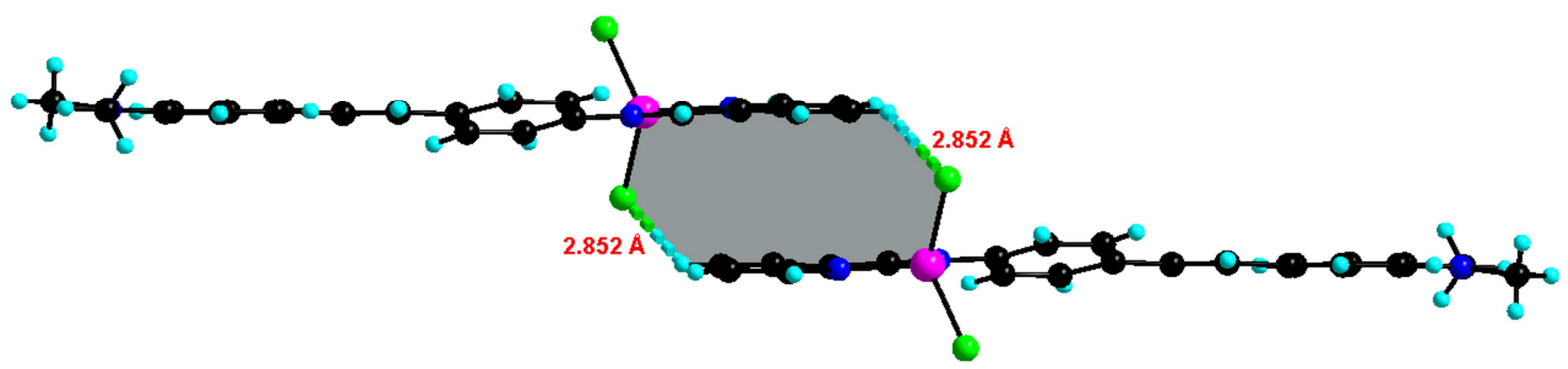

Fig. 2. Two molecules are linked by pairs of weak $\mathrm{C}-\mathrm{H} \cdots \mathrm{Cl}$ hydrogen bonds forming $\mathrm{R}_{2}^{2}(14)$ cyclic pattern in complex $\mathbf{C 1}$.

These interactions lead to the formation of $2 \mathrm{D}$ supramolecular layers parallel to the $a c$ crystallographic plane (Fig. 3).

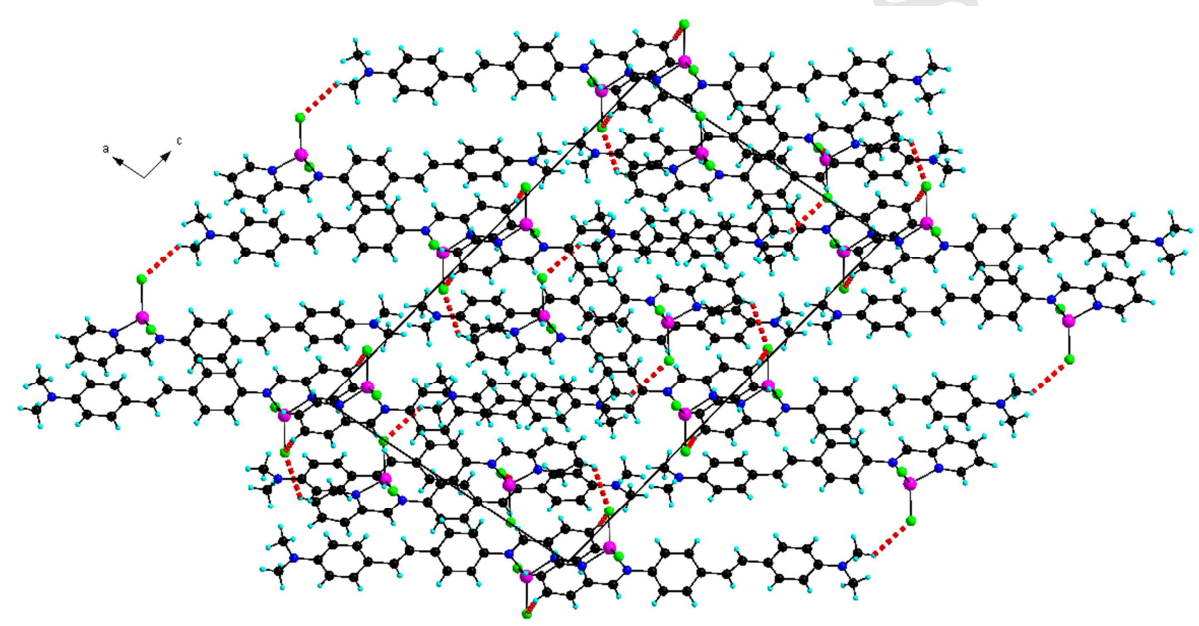

Fig. 3. Pattern of intermolecular contacts in $\mathbf{C 1}$ in the ac plan.

Within the layer, the molecules stack in infinite parallel columns with an offset tail to tail arrangement due to $\pi \cdots \pi$ interactions involving, two by two, the aromatic rings from adjacent molecules (centroid...centroid: $3.64 \AA$, $3.77 \AA$ and $3.72 \AA$ ). The supramolecular interactions between the neighboring molecules are represented in detail in Fig. 4. 


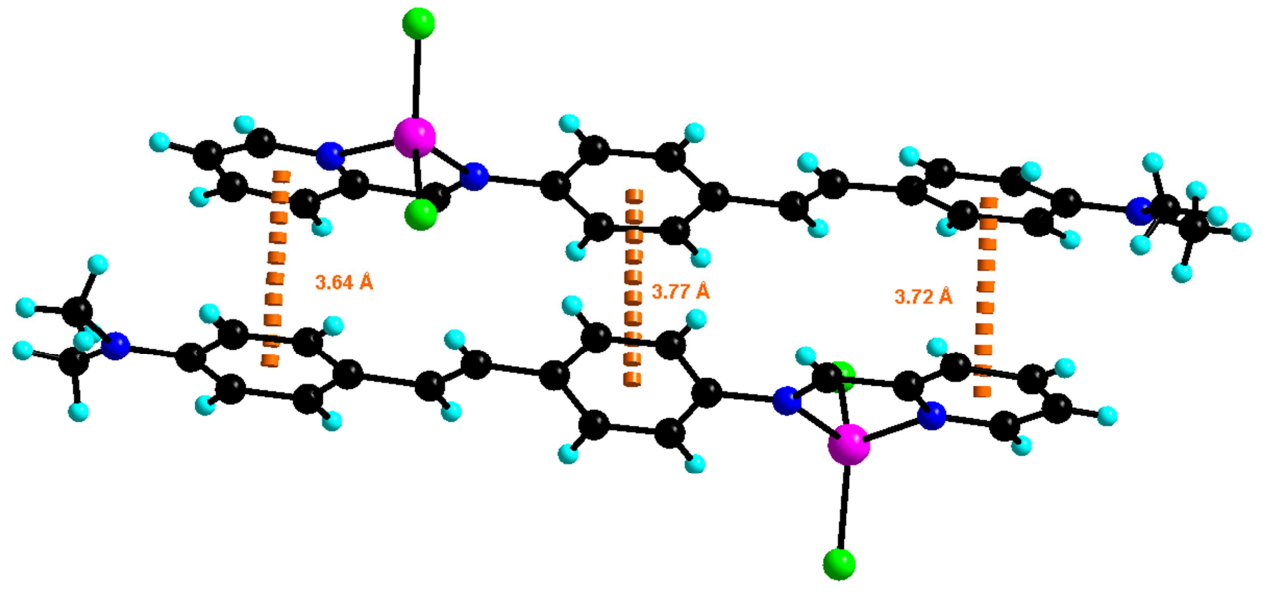

Fig. 4. A perspective of the $2 \mathrm{D}$ supramolecular sheet generated via $\pi \cdots \pi$ stacking interactions between the aromatic rings of the ligands.

\subsubsection{Crystal structure of $\boldsymbol{C 2}$}

Employing the same crystallization technique, namely slow diffusion, single crystals of complex $\left\{\left[\mathrm{Cu}(\mathrm{L1})_{2} \mathrm{CH}_{3} \mathrm{CN}_{3}\right] \mathrm{BF}_{4}\right\} \mathrm{C2}$ were grown and the corresponding crystal structure solved. Complex $\mathbf{C 2}$ crystallizes in the monoclinic system, Cc space group, with half of the complex cationic unit, $\left[\mathrm{Cu}(\mathrm{L} 1)_{2} \mathrm{CNCH}_{3}\right]^{+}$, and half of the uncoordinated $\mathrm{BF}_{4}{ }^{-}$counter anion.

The X-ray crystal analysis of this complex revealed that $\mathrm{Cu}(\mathrm{I})$ ion in $\mathbf{C 2}$ is coordinated in a distorted tetrahedral geometry, which is defined by three nitrogen atoms (two from iminopyridine fragment and one from acetonitrile solvent molecule) and the $\mathrm{C}=\mathrm{C}$ moiety of the olefin from the second ligand (Fig. 5a). Thus each ligand acts as a neutral ditopic spacer to link two $\mathrm{Cu}(\mathrm{I})$ ions by two nitrogen atoms and an olefin moiety to give rise to a $1 \mathrm{D}$ coordination polymer, as depicted in Fig. 5b). This polymer is further stabilized by $\pi \cdots \pi$ stacking interactions ( $\mathrm{ca} .3 .75 \AA$ ) which are probably stabilizing the copper(I)...olefin coordination. Similar copper(I) coordination polymer have been obtained using 4pyridylacrilic acid (which acts as bidentate ligand spacer) in combination with 2,2'-bipyridine [18]. 


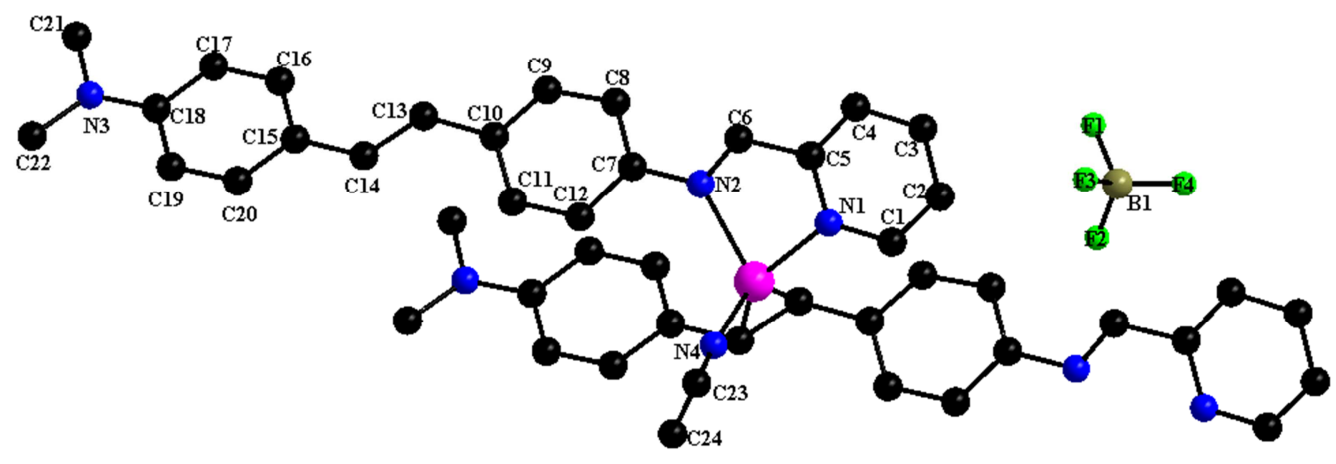

a)

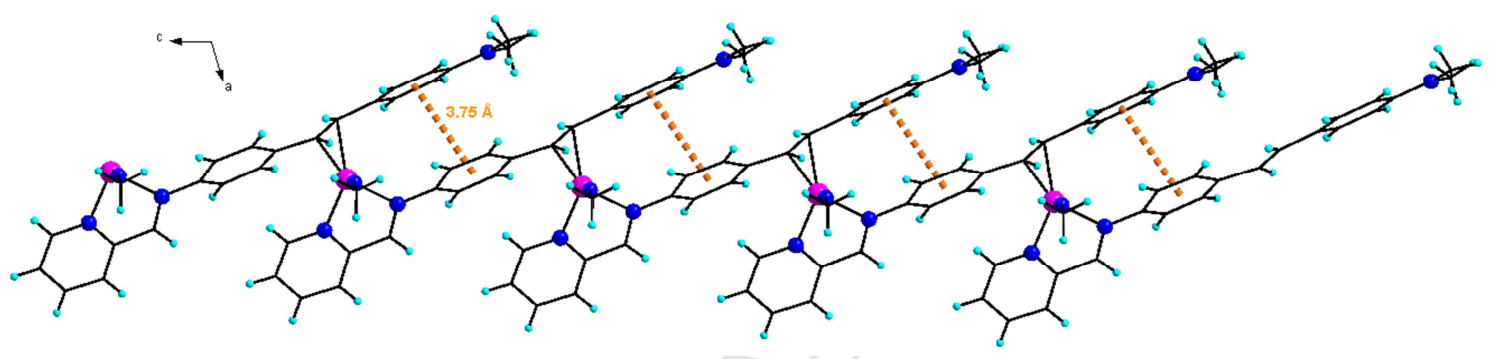

b)

Fig. 5. a) Crystal structure of the monomeric complex $\mathbf{C 2}$ with an atom numbering scheme; b) part of the polymeric chain formed in $\mathbf{C 2}$.

The dihedral angle between the least-square planes of the stilbene fragment and NN-chelate imino-pyridine fragment is $37.26^{\circ}$ in $\mathbf{C 2}$. The lengths of the two $\mathrm{Cu}-\mathrm{N}$ bonds are very close $(\mathrm{Cu} 1-\mathrm{N} 12.051(7) \AA, \mathrm{Cu} 1-\mathrm{N} 22.158(9) \AA$, and Cu1-N4 1.964(7) $\mathrm{A})$, as in complex C1, the formal double bond character in the imino fragment is maintained (C6-N2 1.276(11) $\AA$ ). The $\mathrm{C}=\mathrm{C}$ bond distance $[1.389(11) \AA]$ of the coordinated olefin being longer than the $\mathrm{C}=\mathrm{C}$ bond in complex $\mathbf{C 1}(\mathrm{C}=\mathrm{C}$ equal to $1.34(2) \AA$ ) is coherent with the coordination of the olefin bond and is comparable to the ones found in the $\{[\mathrm{bpy})(4-\mathrm{hpya}) \mathrm{Cu}(\mathrm{I})](\mathrm{BF} 4)\}_{n}$ coordination polymer [1.361(6) $\AA$ ] [18] and in monomeric complexes reported in [24]. In addition, the crystal packing of $\mathbf{C 2}$ (Fig. 6) reveals the presence of two sets of short contacts, $\mathrm{C}-\mathrm{H} \cdots \mathrm{F}$ and $\mathrm{C}-\mathrm{H} \cdots \pi$ which connect the different polymeric chains. 


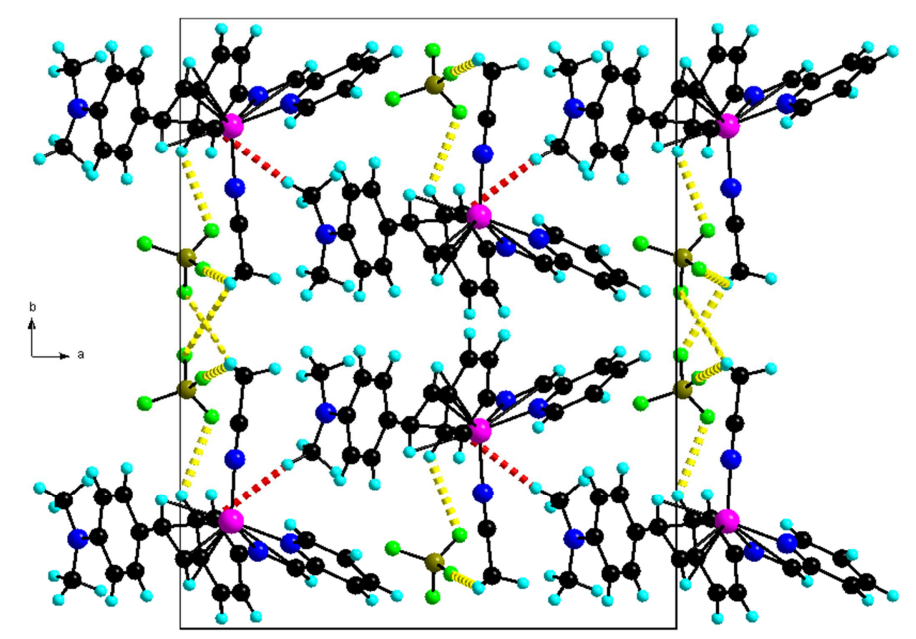

Fig. 6. Crystal packing in complex $\mathbf{C 2}$ with various $\mathrm{C}-\mathrm{H} \cdots \mathrm{F}$ and $\mathrm{C}-\mathrm{H} \cdots \pi$ interactions.

\subsubsection{Crystal structure of $\boldsymbol{C 3}$}

Complex C3 (Fig. 7) crystallizes as dark plates in the monoclinic system, space group $\mathrm{P} 2{ }_{1} / \mathrm{n}$ with one independent molecule in the unit cell. Within this complex the zinc ion is pentacoordinated, the coordination sphere being formed by the three nitrogen atoms of the pincer and two chlorines ions.

The distortion of the geometry around the $\mathrm{Zn}(\mathrm{II})$ ion is caused by the specific requirements of the bis-chelating ligand with small bite angles $\left(\mathrm{N} 2-\mathrm{Zn} 1-\mathrm{N} 374.42(10)^{\circ}\right.$ and $\mathrm{N} 3-\mathrm{Zn} 1-\mathrm{N} 4$ $\left.74.23(10)^{\circ}\right)$. The $\mathrm{Zn}-\mathrm{N}$ (pyridyl) bond $(\mathrm{Zn} 1-\mathrm{N} 32.073(2)$ is shorter than the $\mathrm{Zn}-\mathrm{N}($ imino) bonds (Zn1—N2 2.336(3) $\AA$ and Zn1-N4 2.328(3) $\AA$ ) and the formal double bond character in the imino fragments is maintained $(\mathrm{C} 17-\mathrm{N} 2$ 1.289(4) $\AA$ ) and C23-N4 1.285(4) $\mathrm{A})$.

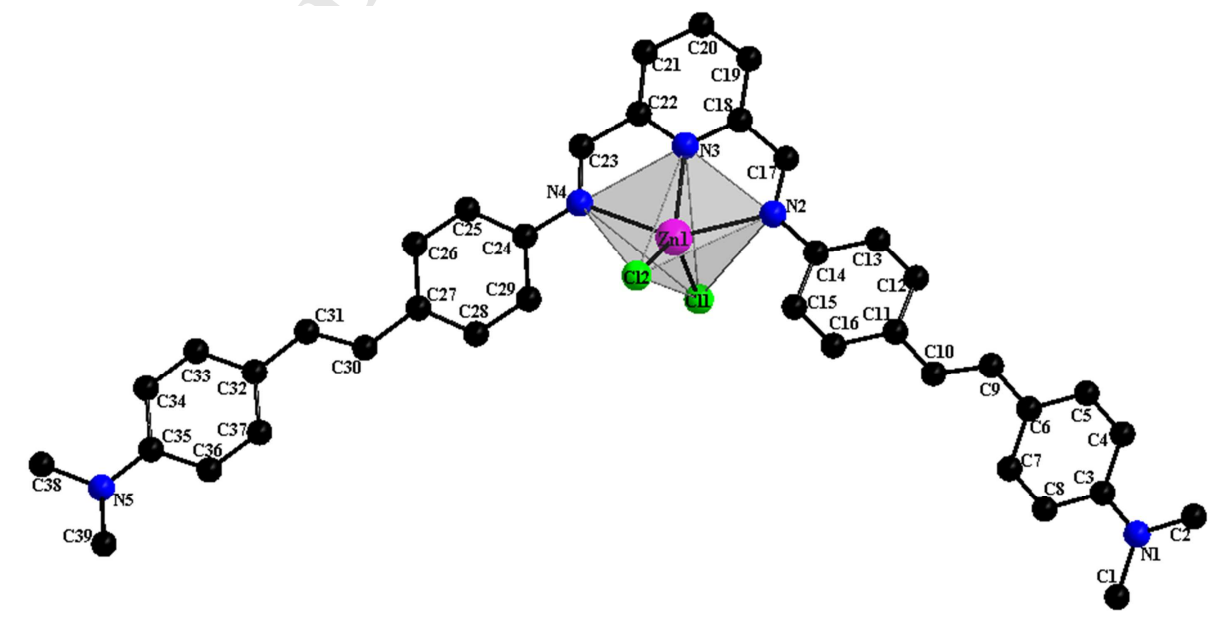

Fig. 7. The crystal structure of complex $\mathbf{C 3}$ with an atom numbering scheme. Hydrogen atoms have been omitted for clarity. 
In the solid state, each chlorine atom in the complex molecule establishes a $\mathrm{C}-\mathrm{H} \cdots \mathrm{Cl}$ weak hydrogen bonding with the hydrogen atoms from the pyridyl unit, the imine as well as with a hydrogen atom form the phenyl ring of the neighboring molecules with distances of 2.723 (7) $\AA$ A, 2.804(8) and 2.713(8) ^, respectively (Fig. 8).

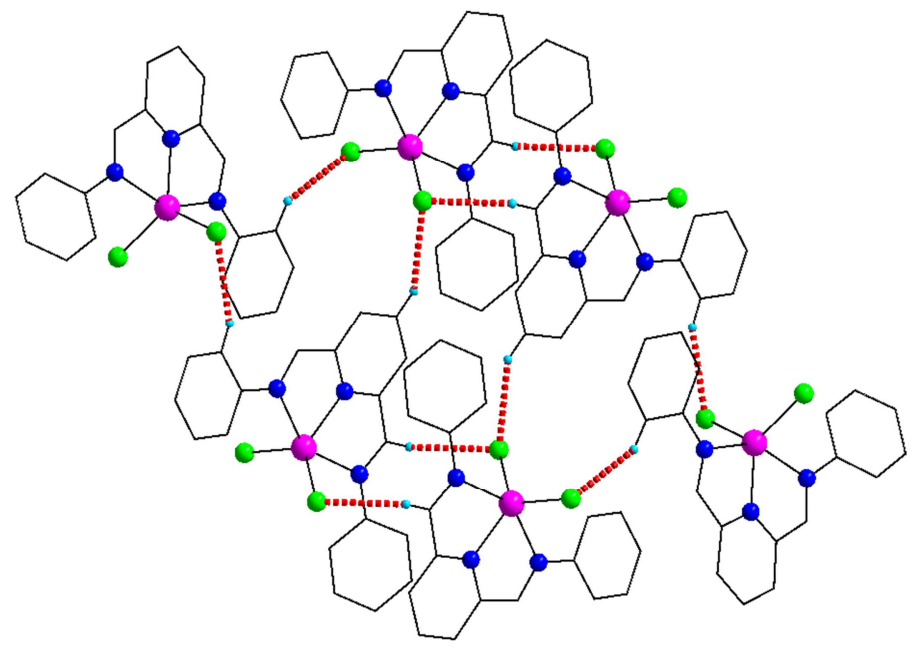

Fig . 8. C-H $\cdots \mathrm{Cl}$ weak hydrogen bonding in complex $\mathbf{C 3}$

As can be seen in Fig. 9, the above mentioned interactions lead to a remarkable molecular arrangement within the metallic complex crystals which results in parallel chain formations along the $\mathrm{b}$ axis. In addition, these chains are stabilized by $\mathrm{C}-\mathrm{H} \cdots \pi$ contacts that occur between the carbon atom from the phenyl ring and the hydrogen atom from the following

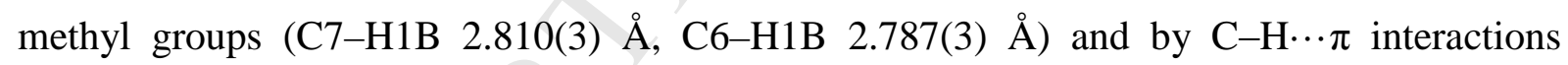
(H1B …centroid $2.70 \AA$ ).

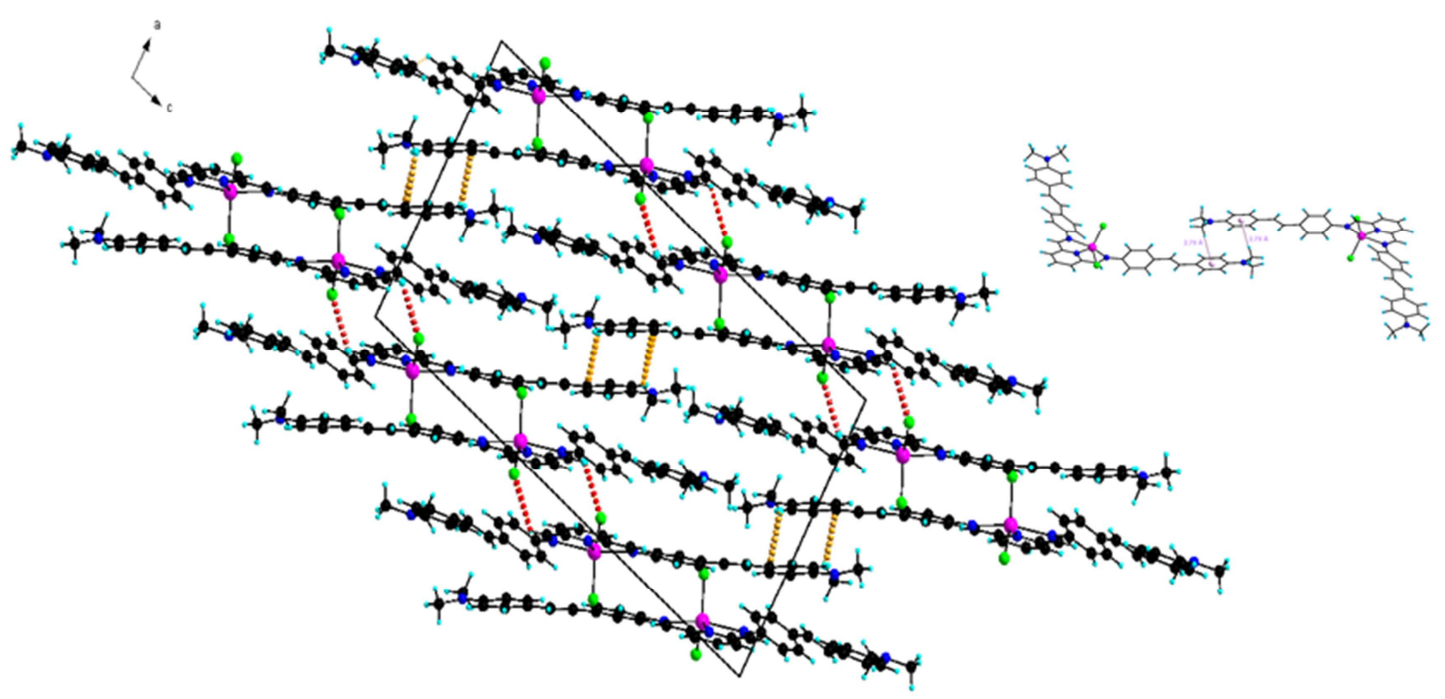


Fig. 9. Molecular arrangement in complex $\mathbf{C 3}$

\subsection{UV-Visible absorption spectroscopy}

The UV-Visible absorption spectra of the ligand $\mathbf{L} \mathbf{1}$ and the two metal complexes $\mathbf{C 1}$ and $\mathbf{C 2}$ were recorded in a dichloromethane solution $\left(\mathrm{C}=2 \times 10^{-5} \mathrm{M}\right)$ at room temperature (Fig. 11a). The ligand exhibits two strong absorption bands at $\lambda=309$ and $397 \mathrm{~nm}$ which are assigned to the $\pi \rightarrow \pi^{*}$ and $n \rightarrow \pi^{*}$ transitions of the stilbene moiety and the iminopyridyl group together with a slight intramolecular charge transfer (ICT) from the dimethylamino donor group to the iminopyridine accepting unit [25]. These bands display a bathochromic shift for both complexes $\mathbf{C 1}$ and $\mathbf{C 2}$ indicating a strong electron accepting behavior of the iminopyridine fragment upon complexation with zinc chloride or with copper cation. As in L1, ligand $\mathbf{L 2}$ exhibit two strong absorption bands $(\lambda=308$ and $398 \mathrm{~nm})$ that are characteristic of $\pi \rightarrow \pi^{*}$ and $n \rightarrow \pi^{*}$ transitions of the stilbene moiety and the iminopyridyl group together with a slight intramolecular charge transfer (ICT) from the dimethylamino donor group to the iminopyridine accepting unit. These bands are red shifted about $100 \mathrm{~nm}$ upon complexation with zinc chloride as it can be seen in Fig. 11b for complex C3.

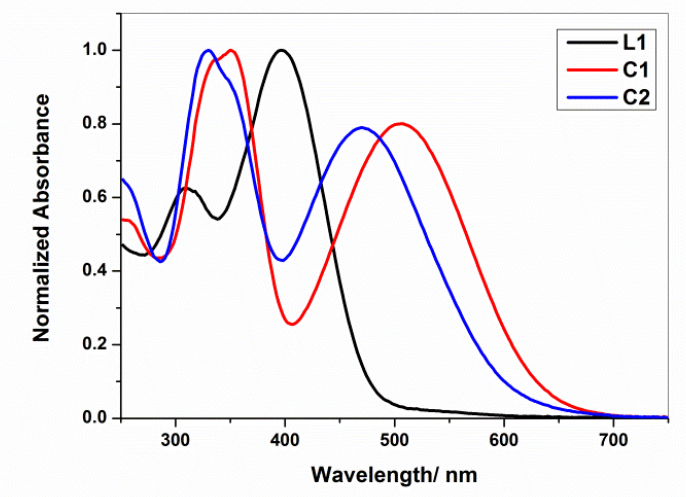

a)

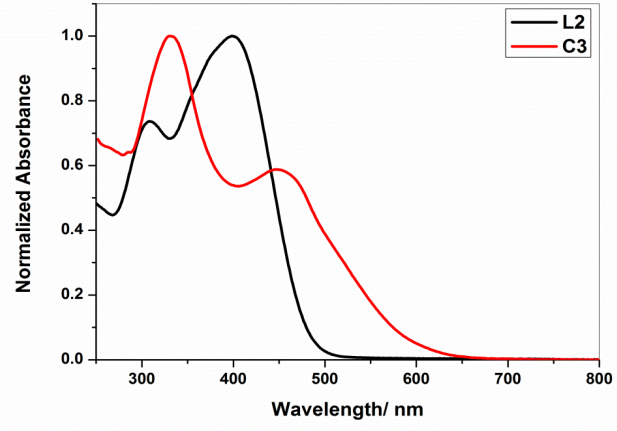

b)

Fig. 11. UV-visible absorption spectra of: a) ligand $L \mathbf{1}$ and complexes C1-C2 and b) Ligand $\mathbf{L 2}$ and complex $\mathbf{C 3}\left(\mathrm{C}=2.510^{-5} \mathrm{M}\right)$ in $\mathrm{CH}_{2} \mathrm{Cl}_{2}$ solution, at room temperature.

In order to confirm the presence in a solution of a single zinc(II) and copper(I) complex species, photometric UV-visible titrations were performed by adding increasing 
amounts of zinc(II) (Fig. 12a) or copper(I) (Fig. 12b) to a $\mathrm{CH}_{2} \mathrm{Cl}_{2}$ solution of ligand $\mathbf{L 1}$. These additions result in the appearance of a new absorption band around 349 and $328 \mathrm{~nm}$ in the case of zinc(II) and copper(I) respectively, which corresponds to a ligand centered (LC, $\left.\pi \rightarrow \pi^{*}\right)$ transition. In addition, a significant bathochromic shift of the absorption band in the visible region can be observed. This shift is indicating an increase of the electron acceptor behavior of ligand L1 upon complexation with zinc(II) or copper(I) which act as strong Lewis acids [21]. The presence of three isosbestic points at 313, 364 and $446 \mathrm{~nm}$ for zinc(II) and at 306, 361 and $436 \mathrm{~nm}$ for copper(I) clearly indicates the formation of just one complex specie in both cases. Note that no additional absorption changes were observed upon the introduction of more than one equivalent of $\mathrm{ZnCl}_{2}$, as expected for the formation of a 1:1 complex, and no additional absorption changes were observed upon the introduction of more than 0.5 equivalent of $\left[\mathrm{Cu}\left(\mathrm{CH}_{3} \mathrm{CN}\right)_{4} \mathrm{BF}_{4}\right]$ indicating the formation of a 1:0.5 complex. This result together with the UV-visible spectrum recorded for C2 (fig. 11a) indicate that in this complex, the polymeric chain observed in the X ray crystal structure is "dissociated" to the mononuclear specie $\left[\mathrm{Cu}(\mathrm{L} 1)_{2} \mathrm{CH}_{3} \mathrm{CN}\right] \mathrm{BF}_{4}$ in which $\mathrm{Cu}(\mathrm{I})$ is coordinated to one ligand $\mathbf{L 1}$ with the iminopyridyl fragment and to the second one with the olefin fragment as can clearly be seen in fig. 5a.

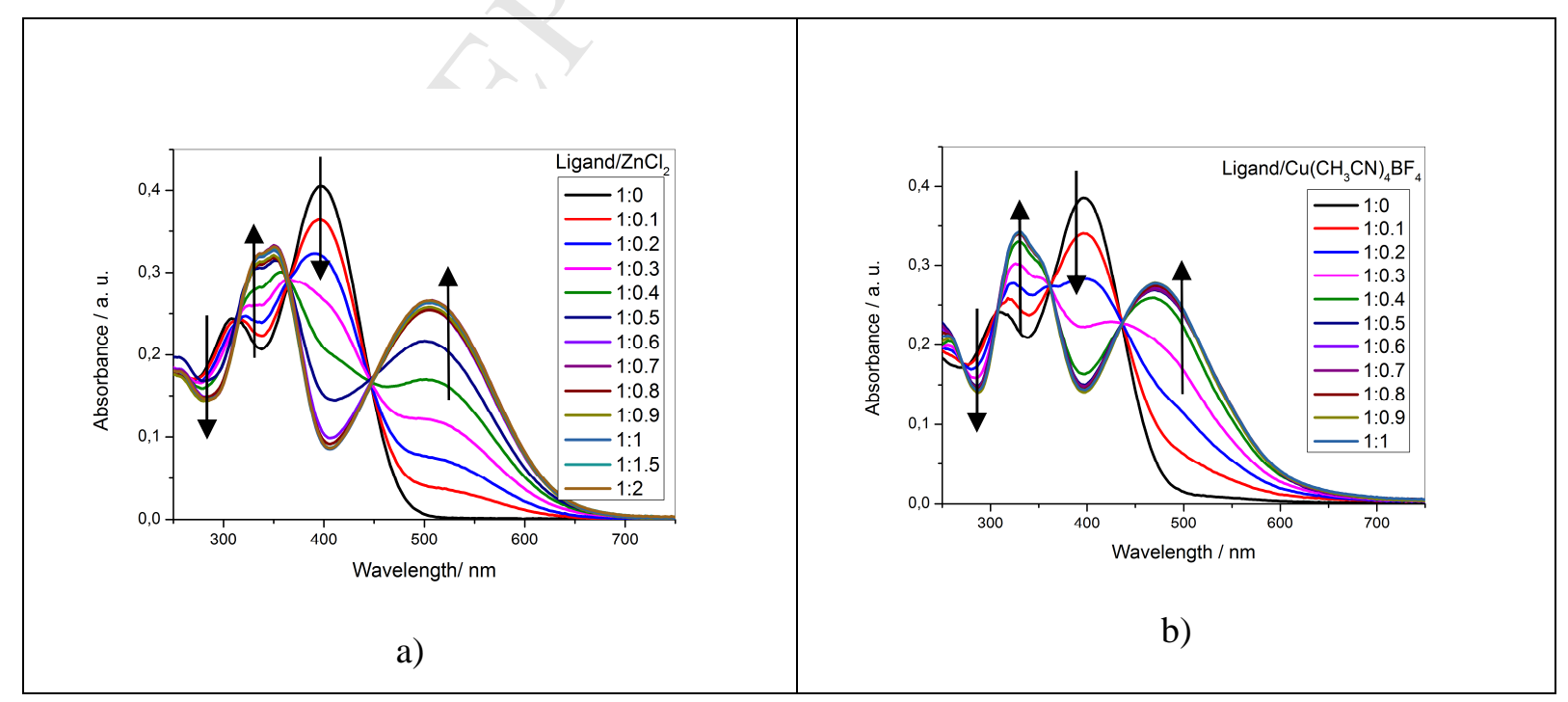




\section{ACCEPTED MANUSCRIPT}

Fig. 12. UV-Visible titration of ligand $\mathbf{L 1}\left(\mathrm{C}=2.510^{-5} \mathrm{M}\right)$ in $\mathrm{CH}_{2} \mathrm{Cl}_{2}$ a) with $\mathrm{ZnCl}_{2}$ and b) with $\left[\mathrm{Cu}\left(\mathrm{CH}_{3} \mathrm{CN}\right)_{4} \mathrm{BF}_{4}\right]$ at room temperature.

\subsection{Computational study}

The Density Functional Theory (DFT) computations have been performed with the Gaussian 09 program [26] using the standard B3LYP [27] functional and the LANL2DZ atomic basis set [28] augmented with polarization function on all atoms, except hydrogen ones. Full geometry optimization in the solvent $\left(\mathrm{CH}_{2} \mathrm{Cl}_{2}\right)$ using the PCM Model [29] of the two ligands (L1, L2) and their corresponding complexes $\left(\mathbf{C 1}=\left[\mathbf{Z n L 1 C l}_{2}\right], \mathbf{C 2}=\left[\mathbf{C u}(\mathbf{L 1})_{\mathbf{2}} \mathbf{C H}_{3} \mathbf{C N}\right]\right.$. and $\mathbf{C 3}=\left[\mathbf{Z n L 2} \mathbf{C l}_{2}\right]$ ) have been carried out first. Then, the computation of the vibration frequencies of all species has been carried out in order to check that the optimized geometries are true minima on the potential energy surfaces.

The computed geometries compare very well with the X-ray ones, but with a small overestimation of the metal-ligand distances of about 4-5\%; such behavior is rather common at the used theoretical level of computation.

The computed frontier Molecular Orbitals (MOs) are displayed on Figure 13.

compounds




C2

compounds




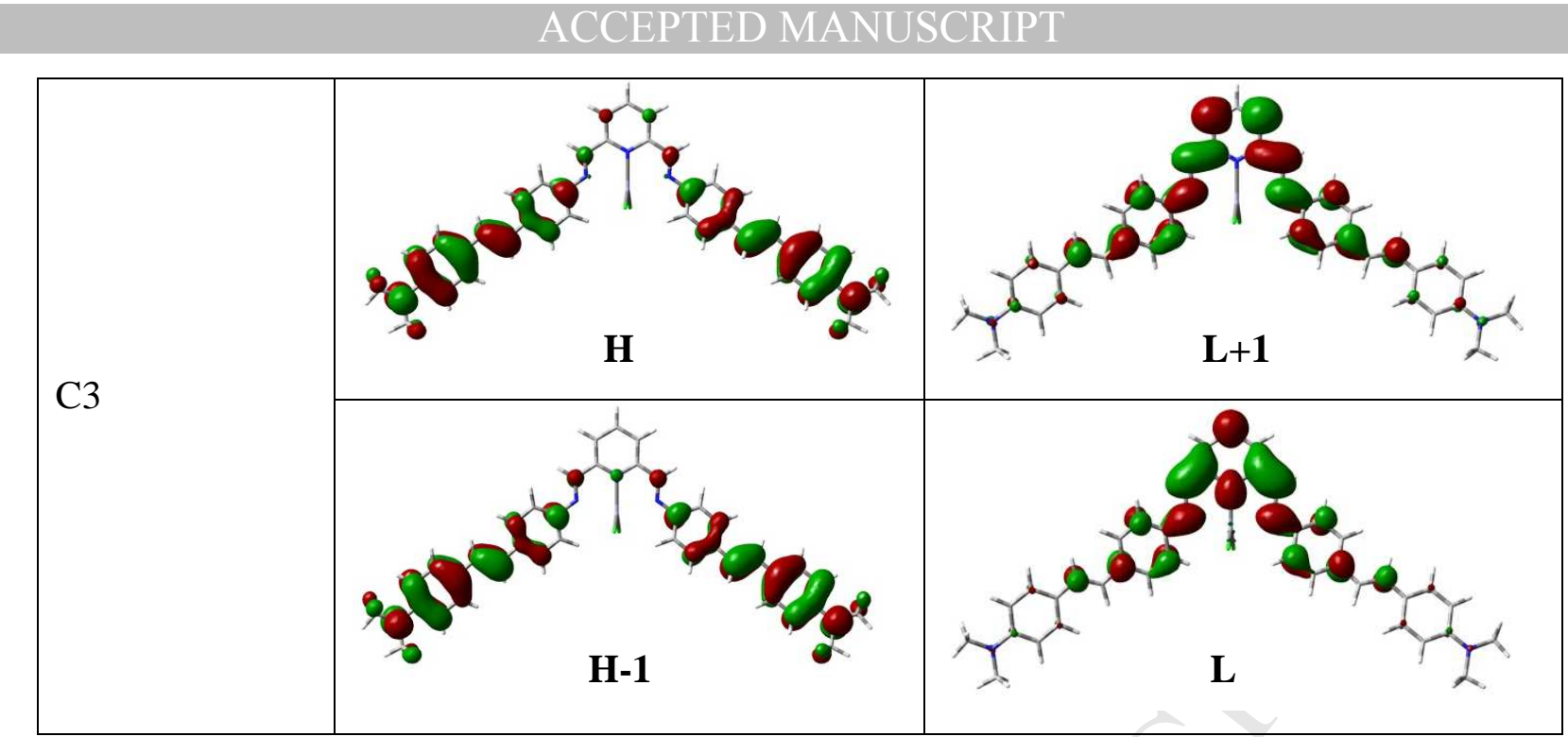

Fig. 13. Frontiers molecular orbitals for ligands L1, L2 and complexes C1, C2 and C3 ( $\mathrm{H}=\mathrm{HOMO}$ and $\mathrm{L}=\mathrm{LUMO})$

The HOMO and HOMO-1 for ligand $\mathbf{L 1}$ are delocalized over the whole $\pi$-conjugated system with a large contribution from the donating dimethylaminobenzene group and a slight contribution of pyridine for the HOMO-1, whereas as expected the electron withdrawing pyridine moiety is dominating in the LUMO and LUMO+1. For the ligand L2 the HOMO and HOMO-1 spread all over the whole $\pi$-conjugated system but on different "arms" of the ligand, with a strong contribution of the dimethylaminobenzene group whereas the LUMO and LUMO+1 are mainly localized on the central pyridine group. It is interesting to note that HOMO and HOMO-1 of $\mathbf{L 2}$ and $\mathbf{C 3}$ are quasi degenerate as well as LUMO and LUMO+1.

Considering the zinc complexes, it is worth noting that the metal center does not contribute to the highest occupied MOs, so that the lowest energy transitions which mainly involve HOMO and HOMO-1 (vide infra) do not exhibit any MLCT character. For these two complexes the occupied MOs with a significant $3 \mathrm{~d}$ character are very low in energy. In the case of the copper complex C2, HOMO and HOMO-1 do not involve the $3 \mathrm{~d}$ metal orbitals, but HOMO-2, HOMO-4, HOMO-5 and HOMO-6 contain a significant metal orbital contribution, so that transitions from these MOs should exhibit a MLCT character.

Vertical excitations energies were calculated using Time Dependent DFT (TD-DFT) [30] using the optimized geometries of the ligands $(\mathbf{L 1}, \mathbf{L 2})$ and the complexes $(\mathbf{C 1}, \mathbf{C 2}$ and $\mathbf{C 3})$, 
in order to assign the observed bands in the UV-visible spectra. The TD-DFT computations have been carried out using the CAM-B3LYP [31] functional, taking into account the solvent $\mathrm{CH}_{2} \mathrm{Cl}_{2}$, our experience showing us that this functional gives spectra in agreement with experimental results [32] for similar species, which exhibit a long distance charge transfer upon excitation. Nevertheless, we checked that CAM-B3LYP leads to a better agreement with experiment than B3LYP, as expected. The obtained computational results, namely the absorption wavelengths $\lambda_{\text {theo }}$ and oscillator strengths $f_{\text {theo }}$, as well as the observed $\lambda_{\text {exp }}$ are given in Tables 2 and 3.

Table 2: Measured $\lambda_{\exp }$ and computed wavelengths $(\mathrm{nm}) \lambda_{\text {theo }}$ at the CAMB3LYP/LANL2DZP level and assignment absorption of low energy bands of L1, C1 and C2

\begin{tabular}{|c|c|c|c|c|}
\hline Compound & $\lambda_{\exp }$ & $\lambda_{\text {theo }}$ & $\mathrm{f}_{\text {theo }}{ }^{\mathrm{a}}$ & Main transitions (\% weights) \\
\hline \multirow{5}{*}{ L1 } & 397 & 403 & 1.832 & $\mathrm{H}->\mathrm{L}(74 \%)$ \\
\hline & 309 & 314 & 0.060 & $\mathrm{H}->\mathrm{L}+1(41 \%) \mathrm{H}-1->\mathrm{L}(24 \%)$ \\
\hline & & & & $\mathrm{H}-5->\mathrm{L}(17 \%)$ \\
\hline & & 288 & 0.048 & $\mathrm{H}->\mathrm{L}+4(49 \%) \mathrm{H}-5->\mathrm{L}(16 \%)$ \\
\hline & & & & $\sqrt{2}$ \\
\hline \multirow{6}{*}{$\mathrm{C} 1$} & 505 & 459 & 1.592 & $\mathrm{H}->\mathrm{L}(79 \%)$ \\
\hline & 351 & 323 & 0.129 & $\mathrm{H}->\mathrm{L}+1(40 \%) \mathrm{H}->\mathrm{L}+2(26 \%)$ \\
\hline & & 307 & 0.358 & $\mathrm{H}-1->\mathrm{L}(19 \%)$ \\
\hline & 258 & 287 & 0.022 & $\mathrm{H}-1->\mathrm{L}(50 \%) \mathrm{H}->\mathrm{L}(18 \%)$ \\
\hline & & 285 & 0.091 & H-3->L(55\%) H->L+3(21\%) \\
\hline & & & & $\mathrm{H}->\mathrm{L}+4(63 \%) \mathrm{H}->\mathrm{L}+5(13 \%)$ \\
\hline \multirow{7}{*}{$\mathrm{C} 2$} & 468 & 439 & 1.288 & $\mathrm{H}->\mathrm{L}(72 \%)$ \\
\hline & & 423 & 0.147 & $\mathrm{H}-1->\mathrm{L}(86 \%)$ \\
\hline & 329 & 394 & 1.691 & $\mathrm{H}-1->\mathrm{L}+1(61 \%)$ \\
\hline & & 366 & 0.115 & $\mathrm{H}-4->\mathrm{L}(46 \%) \mathrm{H}-2->\mathrm{L}(32 \%)$ \\
\hline & 257 & 323 & 0.108 & $\mathrm{H}-2->\mathrm{L}+1(30 \%) \mathrm{H}-1->\mathrm{L}+3(15 \%)$ \\
\hline & & 319 & 0.098 & $\mathrm{H}-1->\mathrm{L}+2(13 \%)$ \\
\hline & & & & $\mathrm{H}->\mathrm{L}+2(33 \%) \mathrm{H}-3->\mathrm{L}(13 \%)$ \\
\hline
\end{tabular}

${ }^{\mathrm{a}}$ Oscillator strength

In agreement with our previous discussion (vide supra) the longest absorption wavelength for $\mathbf{L 1}$ at $\lambda_{\text {exp }}=397 \mathrm{~nm}\left(\lambda_{\text {theo }}=403 \mathrm{~nm}\right)$ corresponds to a $\pi-\pi^{*}$ HOMO-LUMO transition whereas the second absorption band with low intensity at $\lambda_{\exp }=309 \mathrm{~nm}\left(\lambda_{\text {theo }}=314 \mathrm{~nm}\right.$ and $\left.288 \mathrm{~nm}\right)$ is a mixed $\pi-\pi^{*}+\mathrm{n}-\pi^{*}$ excitation, since the HOMO-5 which is involved in the relevant transitions exhibits a lone pair character. 
The same situation occurs for $\mathbf{L} 2$ namely that the low energy band is a $\pi-\pi^{*}$ transition and the high energy one exhibiting also not only a $\pi-\pi^{*}$ character but also a small $n-\pi^{*}$ one, due to the fact that HOMO-3 and HOMO-10 are lone pair MOs.

The batochromic shifts which are observed upon complexation of L1-L2 with $\mathrm{Zn}$ (II) or L1 with $\mathrm{Cu}(\mathrm{I})$, are perfectly reproduced by the TDDFT computations.

In the case of the zinc complexes $\mathbf{C 1}$ and $\mathbf{C 3}$, the nature of the absorption bands are the same as in ligand L1, mainly a $\pi-\pi^{*}$ one. In the case of complex $\mathbf{C 2}$, the high energy bands involving transitions from HOMO-2 and HOMO-4, exhibit not only a $\pi-\pi^{*}$ but also a MLCT one, since the latter MOs possess a significant 3d metal character, their weights being respectively equal to 21 and $52 \%$.

Table 3: Measured $\lambda_{\exp }$ and computed wavelengths (nm) $\lambda_{\text {theo }}$ at the CAMB3LYP/LANL2DZP level and assignment of low energy absorption bands of $\mathbf{L} 2$ and $\mathbf{C 3}$.

\begin{tabular}{|c|c|c|c|c|}
\hline Compound & $\lambda_{\exp }$ & $\lambda_{\text {theo }}$ & $\mathrm{f}_{\text {theo }}$ & Main transitions (\% weights) \\
\hline L2 & 399 & $\begin{array}{l}419 \\
397 \\
327 \\
317 \\
310 \\
307 \\
293\end{array}$ & $\begin{array}{l}2.706 \\
0.919 \\
0.169 \\
\\
0.037 \\
0.018 \\
0.024 \\
0.033\end{array}$ & $\begin{array}{l}\text { H->L(38\%) H-1->L+1(19\%) } \\
\text { H-1->L(34\%) H->L+1(28\%) } \\
\text { H-2->L(20\%) H->L+2(19\%) } \\
\text { H-1->L+1(16\%) } \\
\text { H-1->L+2(19\%) H->L+2(12\%) } \\
\text { H-3->L(12\%) } \\
\text { H->L+1(29\%) H->L }(18 \%) \\
\text { H-1->L+1(28\%) H-1->L(17\%) } \\
\text { H-10->L(11\%) } \\
\text { H-10->L }(27 \%)\end{array}$ \\
\hline C3 & 449 & $\begin{array}{l}470 \\
435 \\
358 \\
355 \\
\\
323 \\
\\
316 \\
308 \\
\\
297\end{array}$ & $\begin{array}{l}2.076 \\
1.042 \\
0.263 \\
0.139 \\
0.028 \\
0.024 \\
0.345 \\
0.155\end{array}$ & $\begin{array}{l}\text { H->L }(57 \%) \mathrm{H}-1->\mathrm{L}+1(19 \%) \\
\mathrm{H}-1->\mathrm{L}(53 \%) \mathrm{H}->\mathrm{L}+1(28 \%) \\
\mathrm{H}-1->\mathrm{L}+1(55 \%) \mathrm{H}->\mathrm{L}(20 \%) \\
\mathrm{H}->\mathrm{L}+1(49 \%) \mathrm{H}-1->\mathrm{L}(38 \%) \\
\text { H-2->L(29\%) H->L+2(14\%) } \\
\mathrm{H}-1->\mathrm{L}+3(13 \%) \\
\mathrm{H}->\mathrm{L}+3(31 \%) \mathrm{H}-1->\mathrm{L}+2(28 \%) \\
\mathrm{H}-2->\mathrm{L}(22 \%) \mathrm{H}-1->\mathrm{L}+3(20 \%) \\
\mathrm{H}->\mathrm{L}+2(19 \%) \\
\mathrm{H}-3->\mathrm{L}(31 \%) \mathrm{H}-2->\mathrm{L}+1(16 \%)\end{array}$ \\
\hline
\end{tabular}

\section{Conclusion}


To summarize, this work should be seen as the continuation of our previous work consisting in the synthesis and the study of the nonlinear optical properties (NLO) of new azobased iminopyridine ligands and metal complexes. We have therefore reported the synthesis of the two stilbene ligands $\mathbf{L} 1$ and $\mathbf{L 2}$. While the complexation of ligand $\mathbf{L 1}$ with zinc(II) afforded a neutral zinc(II) complex formulated as $\left[\mathbf{Z n L 1 C l}_{\mathbf{2}}\right] \mathbf{C 1}$, interestingly its reaction with copper(I) afforded a new stable 1D coordination polymer formulated as $\left\{\left[\mathrm{Cu}(\mathrm{L1})_{2} \mathrm{CH}_{3} \mathrm{CN}\right] \mathrm{BF}_{4}\right\} \mathrm{C2}_{2}$. In addition, complexation of ligand $\mathbf{L 2}$ afforded the neutral zinc(II) complex C3. X-ray crystal structures of these complexes indicate tetrahedral geometry around the $\mathrm{Zn}$ (II) metal ions for $\mathbf{C 1}$ and a distorted tetrahedral geometry around $\mathrm{Cu}(\mathrm{I})$ ion for $\mathbf{C 2}$ in which ligand $\mathbf{L 1}$ is unusually acting as a ditopic spacer for two $\mathrm{Cu}(\mathrm{I})$ with both iminopyridyl and olefin fragments. DFT and TD-DFT computations permitted to assign confidently the observed UV-vis absorption bands of both the ligands and the corresponding metal complexes. The nonlinear optical behaviour (which is an important phenomenon that opens new perspectives for both photonic and opto-electronic applications) of these reported compounds are currently under investigations and will be compared with those of their corresponding azo based compounds and will be reported in due time.

\section{Acknowledgments}

The authors are grateful to GENCI-IDRIS and GENCI-CINES for an allocation of computing time (Grant No. 2016-2017-080649).

\section{Supplementary material}

CCDC 1473154-1473156 contain the supplementary crystallographic data for C1, C2 and C3, respectively, which can be obtained free of charge via http://www.ccdc.cam.ac.uk/conts/retrieving.html. Supplementary data to this article can be found online at http://dx.doi.org/XXXXX.

\section{References}

[1] C-C. Ko, V.W-W. Yam, J. Mater. Chem. 20 (2010) 2063-2070.

[2] (a) R.C. Bertelson, Photochromism, Techniques in Chemistry, ed. G. H. Brown, Wiley Interscience, New York, (1971); (b) H. Dürr, Angew. Chem. Int. Ed. Engl. 28 (1989) 413-431; (c) Photochromism: 
Molecules and Systems, ed. H. Dürr and T. H. Bouas-Laurent, Elsevier, Amsterdam, (1990); (d) Organic Photochromic and Thermochromic Compounds, vol. 1: Main Photochromic Families, ed. J. C. Crano and R. J. Guglielmetti, Plenum Press, New York and London, (1999).

[3] a) J. Crano, W.S. Kwak, C.N. Welch in Applied Photochromic Polymer Systems, ed. C. B. McArdle, Blackie, Glasgow and London, (1992) 31; (b) Organic Photochromic and Thermochromic Compounds, Volume 2, Physicochemical studies, biological applications and thermochromism, ed. J. C. Crano and R. J. Guglielmetti, Plenum Press, New York and London, (1999).

[4] N. Tamai, H. Miyasaka, Chem. Rev. 100 (2000) 1875-1890.

[5] A. Natansohn, P. Rochon, Chem. Rev. 102 (2002) 4139-4175.

[6] T. Muraoka, K. Kinbara, Y. Kobayashi, T. Aida, J. Am. Chem. Soc., 125 (2003) 5612-5613.

[7] A.G. Cheelham, M.G. Hutchings, T.D.W. Claridge, H.L. Anderson, Angew. Chem. Int. Ed. 45 (2006) 1596-1599.

[8] H. Nishihara, Coord. Chem. Rev. 249 (2005) 1468-1475.

[9] A. Bianchi, E. Delgado-Pinar, E. García-España, C. Giorgia, F. Pina, Coord. Chem. Rev. 260 (2014) 156-215.

[10] a) R. Ziessel, A. Harriman, A. El-ghayoury, L. Douce, E. Leize, H. Nierengarten, A. Van Dorsselaer, New J. Chem. 24 (2000) 729-732; b) M.C.Young, A.M. Johnson, A.S. Gamboa, R.J. Hooley, Chem. Commun., 49 (2013) 1627-1629; c) S.E. Howson, A. Bolhuis, V. Brabec, G.J. Clarkson, J. Malina, A. Rodger, P. Scott, Nature Chem. 4 (2012) 31-36.

[11] J.L. Bolliger, A.M. Belenguer, J.R. Nitschke, Angew. Chem. Int. Ed. 52 (2013) 7958-7962.

[12] R.A. Bilbeisi, T.K. Ronson, J.R. Nitschke, Angew. Chem. Int. Ed. 52 (2013) 9027-9030.

[13] a) J. Cloete, S.F. Mapolie, J. Mol. Catalysis A: Chemical 243 (2006) 221-225; b) P. Shejwalkar, N.P. Rath, E.B. Bauer, Dalton Trans. 40 (2011) 7617-7631.

[14] Y-W. Dong, R-Q. Fan, P. Wang, L-G. Wei, X-M. Wang, H-J. Zhang, S. Gao, Y-L. Yang, Y-L. Wang, Dalton Trans. 44 (2015) 5306-5322.

[15] a) J. S. Thompson, R. L. Harlow and J. F. Whitney, J. Am. Chem. Soc., 105 (1983) 35223527; b) F. I. Rodriguez, J. J. Esch, A. E. Hall, B. M. Binder, G. E. Schaller and A. B. Bleeker, Science, 283 (1999) 996-998; c) G. E. Schaller and A. B. Bleeker, Science, 27 (1995) 1809-1811; d) J. R. Ecker, Science, 268 (1995) 667-675.

[16] A. Boni, G. Pampaloni, R. Peloso, D. Belleti, C. Graiff and A. Tiripicchio, J. Organomet. Chem., 691 (2006) 5602-5609.

[17] a) J. S. Thompson and J. F. Whitney, Inorg. Chem., 23 (1984) 2813-2819; b) J. S. Thompson, J. C. Calabrese and J. F. Whitney, Acta Crystallogr., C41 (1985) 890-892.

[18] a) J. Zhang, R.-G. Xiong, J.-L. Zuo and X.-Z. You, Chem. Commun., (2000) 1495-1496; b) J. Zhang, R.-G. Xiong, J.-L. Zuo, C.-M. Che and X.-Z. You, Dalton Trans., (2000) 2898-2900.

[19] M. Munakata, S. Kitagawa, S. Kosome and A. Asahara, Inorg. Chem., 25 (1986) 2622-2627. 
[20] a) G. Nita, D. Branzea, F. Pop, A. El-Ghayoury, N. Avarvari, Crystals. 2 (2012) 338-348; b) K. Iliopoulos, I. Guezguez, A.P. Kerasidou, A. El-Ghayoury, D. Branzea, G. Nita, N. Avarvari, H. Belmabrouk, S. Couris, B. Sahraoui, Dyes and Pigments 101 (2014) 229-233.

[21] I. Guezguez, A. Ayadi, K. Ordon, K. Iliopoulos, D.G. Branzea, A. Migalska-Zalas, M. MakowskaJanusik, A. El-Ghayoury, B. Sahraoui, J. Phys. Chem. C. 118 (2014) 7545-7553.

[22] A. Pino-Cuevas, R. Carballo, L. Muñoz, E.M. Vázquez-López, Eur. J. Inorg. Chem. (2015) 4402-4411.

[23] C. Wu, J. Wei, D. Tian, Y. Feng, R.H. Miller, Y. Wang, J. Med. Chem. 51 (2008) 6682-6688.

[24] J-J. Allena and A-R. Barron, Dalton Trans., (2009) 878-890.

[25] Y. Zhao, V. Khodorkosky, J. Cohen, Z. Priel, J. Photochem.Photobiol. A: Chem. 99 (1996) 23-28.

[26] M. J. Frisch, G. W. Trucks, H. B. Schlegel, G. E. Scuseria, M. A. Robb, J. R. Cheeseman, G. Scalmani, V. Barone, B. Mennucci, G. A. Petersson, H. Nakatsuji, M. Caricato, X. Li, H. P. Hratchian, A. F. Izmaylov, J. Bloino, G. Zheng, J. L. Sonnenberg, M. Hada, M. Ehara, K. Toyota, R. Fukuda, J. Hasegawa, M. Ishida, T. Nakajima, Y. Honda, O. Kitao, H. Nakai, T. Vreven, J. A. Montgomery Jr., J. E. Peralta, F. Ogliaro, M. Bearpark, J. J. Heyd, E. Brothers, K. N. Kudin, V. N. Staroverov, R. Kobayashi, J. Normand, K. Raghavachari, A. Rendell, J. C. Burant, S. S. Iyengar, J. Tomasi, M. Cossi, N. Rega, J. M. Millam, M. Klene, J. E. Knox, J. B. Cross, V. Bakken, C. Adamo, J. Jaramillo, R. Gomperts, R. E. Stratmann, O. Yazyev, A. J. Austin, R. Cammi, C. Pomelli, J. W. Ochterski, R. L. Martin, K. Morokuma, V. G. Zakrzewski, G. A. Voth, P. Salvador, J. J. Dannenberg, S. Dapprich, A. D. Daniels, O. Farkas, J. B. Foresman, J. V. Ortiz, J. Cioslowski, D. J. Fox, Gaussian 09, revision D.01, Gaussian, Inc., Wallingford, CT, 2009.

[27] a) C. Lee, W. Yang, R.G. Parr, Development of the Colle-Salvetti, Phys. Rev. B 37 (1998) 785. b) A. D. Becke, J. Chem. Phys. 98 (1993) 5648. c) P. J. Stephens, F. J. Devlin, C. F. Chabalowski, M. J. Frisch, J. Phys. Chem. 98 (1994) 11623-11627.

[28] P. J. Hay, W.R. Wadt, J. Chem. Phys. 82 (1985) 270.

[29] a) S. Miertus, E. Scrocco, J. Tomasi, Chem. Phys. 55 (1981) 117-129; b) V. Barone, M. Cossi, J. Tomasi, J. Chem. Phys. 107 (1997) 3032-3041. c) M. Cossi, G. Scalmani, N. Rega, V. Barone, J. Chem. Phys. 117 (2002) 43.

[30] a) M. E. Casida, in Recent Advances in Density Functional Methods; D. P. Chong, Ed.; World Scientific: Singapore, Vol. 1 (1995) p 155. b) E. K. U. Gross, J. F. Dobson, M. Petersilka, in Density Functional Theory II; R. F. Nalewajski, Ed.; Springer: Berlin, Topics in Current Chemistry, Vol. 181 (1996) p 81

[31] T. Yanai, D. P. Tew, N. C. Handy, Chem. Phys. Lett. 393 (2004) 51-57

[32] A. Ayadi, D. G. Branzea, M. A. Benmensour, A. Boucekkine, N. Zouari, A. El-Ghayoury, Tetrahedron. 71 (2015) 7911-7919. 


\section{Highlights}

- Two stilbene based iminopyridine ligands (L1-L2) have been prepared.

- Corresponding Zinc(II) and copper(I) have been structurally characterized.

- TDDFT calculations used to assign the UV-Visible absoprtion bands. 